\title{
Türkiye İnsan Hakları ve Eşitlik Kurulu'nun Ayrımcılık Yasağının İhlali Kapsamında İdari Yaptırım Yetkisi
}

\author{
Human Rights and Equality Board of Turkey's Administrative Sanction \\ Power for Violation of Prohibition of Discrimination
}

\author{
Hulusi Alphan Dinçkol * (iD
}

\section{öz}

06.04.2016 tarihinde yürürlüğe girmiş olan 6701 sayılı Türkiye İnsan Hakları ve Eşitlik Kurumu Kanunu, insan haklarının korunması anlamında kurumsallaşmayı sağlamıştır. Özellikle Paris Prensipleri ile gelişen ulusal insan hakları kurumlarının kurulması yönünde uluslararası fikir birliği, bu kanunun iç hukukumuz tarafından kabul edilmesi gerekliliğini ortaya çıkarmıştır. Sadece özel hukuk kişileri üzerinde değil, ayrıca kamu idareleri ve kamu kurumları üzerinde de insan hakkı ihlallerinin idari denetim yolu, bu sayede açılmış olmaktadır. 6701 sayılı Kanun TİHEK’i, diğer ulusal insan haklarının korunması kapsamında faaliyet gösteren kamu kurumlarından ayrıştırmaktadır. Ayrımcılık yasağını ihlal edenlere karşı yapılacak inceleme sonucu idari yaptırım yetkisinin uygulanabilmesi kabiliyeti, ulusal normlar bakımından emsal örnek olarak karşımıza çıkmaktadır. TïHEK’in organlarından olan Türkiye İnsan Hakları ve Eşitlik Kurulu, karar alma yetkisine sahip bağımsız bir idari birimdir. $\mathrm{Bu}$ niteliği ile Kurul, yapılan ihlal başvuruları üzerine harekete geçebileceği gibi, resen de inceleme başlatabilir.

Anahtar Kelimeler: Türkiye İnsan Hakları ve Eşitlik Kurumu, Ayrımcılık Yasağı, İdari Yaptırım, Düzenleyici ve Denetleyici Kurum, İdari Başvuru

\section{ABSTRACT}

The Law for Human Rights and Equality Institution of Turkey which was accepted on 06.04.2016, provides institutionalization in terms of protecting human rights. In particular, the consensus on the establishment of national human rights institutions which developed with the Paris Principles has revealed the need for this law to be adopted by our domestic law. The way of administrative control of human rights violations not just only on people, but also on administrations is thus opened. Law No. 6701 distinguishes TİHEK from other regulatory agencies operating within the scope of the protection of human rights. In terms of national law, the ability to apply administrative sanction as a result of the investigation against those who violate the prohibition of discrimination emerges as a precedent example. One of the organs of TİHEK is Human Rights and Equality Board of Turkey which is an independent administrative unit with decisionmaking power. With this characteristic, the Board can take action upon the applications of violations or initiate an investigation ex officio.

Keywords: Human Rights and Equality Institution of Turkey, Prohibition of Discrimination, Administrative Sanction, Regulatory Agency, Appeal to Administration

\footnotetext{
* Dr. Öğr. Üyesi, Maltepe Üniversitesi Hukuk Fakültesi İdare Hukuku Anabilim Dalı
}

Sorumlu Yazar/Correspondence Author: Hulusi Alphan Dinçkol

E-posta/E-mail: alphandinckol@maltepe.edu.tr, 


\section{GíRiş}

İnsan haklarının korunması, haklara olası saldırıların önlenmesi, ihlal edilen hakların ihlal öncesine döndürülmesinin ya da tazmininin sağlanması bakımından insan hakları konusu, dünya tarihinde tüm toplumların ilgilendiği bir alan olarak karşımıza çıkmaktadır. Tüm insanlığı ilgilendiren bu alan öncelikle uluslararası toplumda karşılık bulmuştur. Özellikle II. Dünya Savaşı sonrası, insan haklarının korunmasında kurumsallaşma fikri ön plana çıkmaya başlamıştır. Her devletin kendi kurumları tarafından insan haklarının korunması yönünde çalışması, uluslararası hukuk süjeleri tarafından konunun irdelenmesi ile daha da kuvvetlenmiştir.

İnsan haklarının kurumsallaşması bağlamında ilk adım, 1946 yılında Birleşmiş Milletler Ekonomik ve Sosyal Konseyi'nde atılmıştır ${ }^{1}$. II. Dünya Savaşı'nın yaralarını sarmakla çaba harcayan BM, ulusal anlamda bu korumayı sağlayacak olan kurumların oluşturulması bakımından tüm üye devletlere çağrıda bulunmuştur. Yıllar boyunca bu kapsamda çalışmalarda bulunan BM, 1991 yılı geldiğinde “İnsan Haklarının Korunması ve Güçlendirilmesi İçin Ulusal Kurumlar" konulu bir çalıştay düzenlemiş ve sonrasında 20.12.1993 tarihinde gerçekleştirilen Viyana İnsan Hakları Konferansı'nda, Paris Prensipleri adı verilen ulusal insan hakları koruma kurumlarının kurulması gerekliliğini temel bir ilke olarak kabul etmiştir² ${ }^{2}$

Paris Prensipleri ile ele alınan en önemli konular, insan haklarının geliştirilmesi ve korunması için kurulması gereken ulusal kurumların statüsü ve en verimli şekilde çalışabilmesi için bu kurumların sahip olması gereken özelliklerinin belirlenmesi hususlarıdır ${ }^{3}$. Paris Prensipleri kapsamında ulusal insan hakları kurumlarının gerçek anlamda faaliyet gösterebilmeleri adına gerekli olan özellikler;

- Kurumun anayasal ve yasal dayanağa sahip olmasılyla güvenceye alınması,

- Hükümetten ayrı bağımsız ve özerk bir tüzel kişiliğe sahip olması,

- İnsan haklarının korunması ve güçlendirilmesi için geniş yetkilere sahip olması,

- Kurumun üye seçiminde toplumun tümünü yansıtabilmesi için çoğulcu ve bağımsız bir yapıya sahip olmas1,

- Faaliyette bulunabilmesi adına yeterli mali kaynağa ve özerkliğe sahip olması ve

- Sivil toplum ile devlet arasında köprü vazifesi görmesi

olarak sıralanmaktadır ${ }^{4}$.

Türk hukuk sistemi bakımından bu alanda faaliyet gösteren Türkiye İnsan Hakları ve Eşitlik Kurumu’nun (TİHEK) incelenmesi son derece önem taşımaktadır. TİHEK'in hukuki yapısının yanı sıra, özellikle yaptırım uygulama gücünün inceleme altına alınması bu çalışmanın esasını oluşturmaktadır.

1 https://www.tihek.gov.tr/bm-ve-ulusal-insan-haklari-kurumlari/ (Erişim tarihi: 21.02.2021).

2 https://www.tihek.gov.tr/bm-ve-ulusal-insan-haklari-kurumlari/ (Erişim tarihi: 21.02.2021).

3 Zehra Odyakmaz / Bayram Keskin / Yusuf Deniz, “6701 Sayılı Türkiye İnsan Hakları ve Eşitlik Kurumu Kanunu Üzerine Bir Değerlendirme - I”, Uyuşmazlık Mahkemesi Dergisi, Sayı: 7, 2016, s.727.

4 https://www.tihek.gov.tr/bm-ve-ulusal-insan-haklari-kurumlari/ (Erişim tarihi: 21.02.2021). 
Çalışmada TİHEK'in kurumsal yapısı bağlamında onun bir organı olan Türkiye İnsan Hakları ve Eşitlik Kurulu’nun yapısının inceleme altına alınmasının yanı sıra kurulun özellikle yaptırım uygulama fonksiyonu üzerinde durulacak ve değerlendirilecektir. Yine çalı̧̧ma içerisinde TİHEK'in idari yaptırım yetkisi ele alınırken, kurumun tüzel kişiliğinin benzer kurumlarla karşılaştırılması da yapılacaktır. Ayrıca kurumun emsal kararları ışığında idari yaptırım yetkisinin kullanılmasına ya da kullanılmamasına dair verilecek kararlara karşı başvuru yollarının farklılıkları üzerinde durulacaktır.

\section{TÜRKIYE INSAN HAKLARI VE EŞITLIK KURUMU'NUN KURULUŞU, HUKUKi NiTELIĞi, IDARi TEŞKILAT IÇINDEKI YERI VE ORGANLARI}

\section{A. TÜRKIYE INSAN HAKLARI VE EŞITLIK KURUMU'NUN KURULUŞ SÜRECi}

Türkiye Cumhuriyeti’nde insan haklarının korunmasındaki kurumsallaşma süreci 80'li yıllara dayanmaktadır. 80'li yılların sonlarında Devlet Planlama Teşkilatı’nın kadın haklarına yönelik faaliyetleri, insan haklarının devlet tarafından korunması anlamında kurumsallaşma yoluna gidildiğinin bir örneği olarak karşımıza çıkmaktadır ${ }^{5}$. Daha sonrasında 1987'de Avrupa Birliğine yapılmış olan tam üyelik başvurusu doğrultusunda 1990'da insan haklarının kurumsallaşması süreci devam etmiştir6́. Kadın ve Aileden Sorumlu Bakanlığa bağlı Kadın Statüsü ve Sorunları Genel Müdürlügü̉nün oluşturulduğu yıl olan 1990'da ayrıca Türkiye Büyük Millet Meclisi İnsan Hakları İnceleme Komisyonu kurulmuş ve göreve başlamıştır .

2000’li yıllara gelindiğinde yürütme erki içerisinde kurumsallaşma daha yoğun görünmeye başlamıştır. Başbakanlık Merkez Teşkilatı Kanunu ile gerçekleştirilen değişiklikle İnsan Hakları Başkanl $\breve{g ̆}_{1}^{8} 2001$ yllında kurulmuş ve insan haklarına ilişkin idari ve kanuni düzenlemelerin yapılması amacıyla faaliyette bulunacak ve tavsiye verecek İnsan Hakları Üst Kurulu oluşturulmuştur ${ }^{9}$. Ayrıca il ve ilçe bazında faaliyet göstermesi planlanan İl ve İlçe İnsan Hakları Kurulları oluşturulması, bu kurulların vali, kaymakam, belediye başkanı ve çeşitli kamu kurumlarının yönetici nitelikli görevlilerinin yer alacağı şekilde teşkilatlanması amaçlanmıştır ${ }^{10}$. Ancak sonrasında bu kurullara sivil toplum kuruluşlarından da üyeler katılmıştır.

5 Ümran Güneş, “Türkiye’de İnsan Haklarının Korunmasına İlişkin Ulusal İnsan Hakları Kurumları: Kamu Denetçiliği Kurumu ve Türkiye Insan Hakları ve Eşitlik Kurumu”, Trakya Üniversitesi Sosyal Bilimler Dergisi, Cilt: 20, Sayı: 1, Haziran 2018, s.173.

6 Vahap Atilla Oğuşgil, “Avrupa Birliği Yolunda Türkiye İnsan Hakları Kurumu’nun Birleşmiş Milletler Paris Prensipleri Işığında Değerlendirilmesi”, Bilig (Türk Dünyası Sosyal Bilimler Dergisi), Sayı: 74, Yaz 2015, s.178.

7 Güneş, s.173.

$8 \quad$ Mülga 4643 sayı ve 12.04.2001 kabul tarihli Başbakanlık Teşkilâtı Hakkında Kanun Hükmünde Kararnamenin Değiştirilerek Kabulü Hakkında Kanunda Değişiklik Yapılmasına Dair Kanun Hükmünde Kararnamenin Değiştirilerek Kabulü ile Genel Kadro ve Usulü Hakkında Kanun Hükmünde Kararnamenin Eki Cetvellerde Değişiklik Yapılmasına İlişkin Kanun.

9 Odyakmaz / Keskin / Deniz, s.731.

10 Personelinin merkezi ve yerinden yönetim idareleri içinden gelmesi nedeniyle bu kurulların bağımsızlığı üzerinde tartışmaların ortaya çıktığına dair görüş için bakınız Güneş, s.178. 
Kurumsallaşma yönünde sonraki gelişmeler bakımından Avrupa Birliği’nin etkisi giderek artmıştır. $\mathrm{Bu}$ sayede 2008 yılında kurumsallaşma sürecinin farklı bir hızlanma yakaladı̆̆ı görülmektedir. 18.02.2008 tarihinde Avrupa Birliği Konseyi tarafından yayımlanan "Katılım Ortaklığı Belgesi” ile Birleşmiş Milletler Paris İlkeleri’ne uygun ve yeterli mali kaynağı olması gereken bağımsız ulusal insan hakları kurumlarının oluşturulması gerekliliği hüküm altına alınmıştır ${ }^{11}$. Bu kapsamda yapılan çalışmalar üzerine 2012 yılında 6332 sayılı Türkiye İnsan Hakları Kurumu Kanunu yayımlanmış ve insan haklarının korunması ve geliştirilmesi konusunda çalışmalar yapmak amacıyla kurum (TİHK) varlık bulmuştur ${ }^{12}$.

TİHK, insan haklarının korunabilmesi için birçok işlem ve eylemi gerçekleştirebilecek şekilde görev ve yetkilerle donatılmıştır ${ }^{13}$. Kurumun karar organı olan kurulun idari yaptırım yetkisine sahip olmaması, kurumun ağırlıkla insan hakkı ihlallerini tespit etmek ya da insan haklarının korunması ve geliştirilmesi kapsamında yetkisi olduğunu göstermektedir ${ }^{14}$. Diğer bir deyişle kurulun alacağ1 kararların kesin hüküm olmadığı, sadece tavsiye niteliğinde olduğu anlaşılmaktadır ${ }^{15}$.

İdari yaptırım yetkisine sahip olmayan TİHK ile Başbakanlığa bağlı olan İnsan Hakları Başkanlığı, farklı nitelikteydi. İnsan Hakları Başkanlığı 2001 yılında idari teşkilatta kendisine Başbakanlık çatısı altında yer bulmuşken, TİHK kamu tüzel kişiliğini haiz bir biçimde idari ve mali özerkliğe sahip olarak kurulmuştur ${ }^{16}$. Bu doğrultuda TİHK ile insan haklarının korunması adına ilk defa merkezi idareden ayrı bir idari kurumun oluştuğu söylemek yanlış olmayacaktır.

2013 yılında TİHK kapsamında yeni bir düzenlemeye gidilmiştir. İşkenceye ve Diğer Zalimane, Gayriinsani veya Küçültücü, Muamele veya Cezaya Karşı Birleşmiş Milletler Sözleşmesi’ne Ek İhtiyari Protokol doğrultusunda ulusal izleme ve önleme yapacak bir teşkilatlanmanın kurulması ihtiyacı doğmuştur. Bu doğrultuda insan hakkı ihlallerinin önlemesi yetkisi, Bakanlar Kurulu’nun 09.12.2013 tarih ve 2013/5711 sayılı Kararıyla TİHK’e tanınmıştır ${ }^{17}$.

11 Oğușgil, s.178.

1228339 sayı ve 30.06.2012 tarihli Resmi Gazete'de yayımlanan Mülga 6332 sayı ve 21.06.2012 kabul tarihli Türkiye İnsan Hakları Kurumu Kanunu.

13 Mülga 6332 sayılı Türkiye İnsan Hakları Kurumu Kanunu’nun “Görev ve yetkiler” başlıklı 4. maddesi uyarınca; "Kurum, insan haklarının korunmasına, geliştirilmesine ve ihlallerin önlenmesine yönelik çalışmalar yapmak; işkence ve kötü muamele ile mücadele etmek; şikâyet ve başvuruları incelemek ve bunların sonuçlarını takip etmek; sorunların çözüme kavuşturulması doğrultusunda girişimlerde bulunmak; bu amaçla eğitim faaliyetlerini yürütmek; insan hakları alanındaki gelişmeleri izlemek ve değerlendirmek amacıyla araştırma ve incelemeler yapmakla görevli ve yetkilidir".

14 Kurulun görev ve yetkilerinin daha detaylı incelenebilmesi için bakınız mülga 6332 sayılı Türkiye İnsan Hakları Kurumu Kanunu'nun "Kurulun görev ve yetkileri" başlıklı 7. maddesi.

15 Odyakmaz / Keskin / Deniz, s.731.

16 Mülga 6332 sayılı Türkiye İnsan Hakları Kurumu Kanunu’nun "Kuruluş ve statü” başlıklı 3. maddesi uyarınca; “(1) Bu Kanunla ve ilgili diğer mevzuatla verilen görevleri yerine getirmek ve yetkileri kullanmak üzere, kamu tüzel kişiliğini haiz, idari ve mali özerkliğe sahip ve özel bütçeli, Türkiye İnsan Hakları Kurumu kurulmuştur

(2) Kurum Başbakanlıkla ilişkilidir".

17 Abdurrahman Eren, 12-13 Haziran 2015 tarihinde sunulan bildiri, Ulusal İnsan Hakları Kurumları (İyi Uygulama Örnekleri ve Deneyim Paylaşımı) Uluslararası Konferansı, İstanbul, Kasım 2015, s.42; Fatih Düğmeci, Türkiye İnsan Hakları ve Eşitli Kurumu'nun Yapısı ve İdare Üzerindeki Ayrımcılık Denetimi, 1. Baskı, Adalet Yayınevi, Ankara, 2019, s.237. 
İdari teşkilat düzenlemesi bakımından ayrı bir kamu tüzel kişiliği ile ayrımcllıkla mücadele etmeye ilişkin planlanan görev ve faaliyetlerin, 2016 yıllnda TïHK bünyesinde toplanması düşüncesi ortaya çıkmıştır. Bu kapsamda TİHK’in tüzel kişiliğine son verilerek Türkiye İnsan Hakları ve Eşitlik Kurumu (TIHEK) kurulmuş ve yeni kurulan bu kuruma ayrımcılıkla mücadele etme yetkisi de tanınmıştır ${ }^{18}$. 6701 sayılı Türkiye İnsan Hakları ve Eşitlik Kurumu Kanunu ile TİHK'in yerine kurulmuş olan TİHEK, selefi olan TİHK'in görev ve yetkilerini devralmış ve ayrıca ayrımcılı̆̆ın önlenmesi kapsamında da idari işlem tesis edebilme gücüne sahip olmuştur ${ }^{19}$. Ayrımcılık ile etkin bir mücadele sergilenebilmesi adına yapılan bu değişiklik ile Anayasảnın 10. maddesi kapsamında kanun önünde eşitlik ilkesi ile Türkiye’nin taraf olduğu çeşitli insan hakları sözleşmelerinin gereklerinin sağlanması amaçlanmıştı ${ }^{20}$. Uluslararası boyutta özellikle Avrupa Birliği müktesebatına uyumun sağlanması da amaçlardan bir diğeridir ${ }^{21}$. Kanunun genel gerekçesinde de ayrımcılık yasağının TİEHK dışında ayrı bir tüzel kişilik ile gözetilmesine ihtiyaç olmadığına dair açıklama yer almaktadır ${ }^{22}$.

TİHEK, TİHK gibi Başbakanlıkla ilişkili bir kurum olarak kurulmuştur. Fakat 2017 yılında yapılmış olan Anayasa değişikliği TİHEK'in yeniden şekillenmesine neden olmuş ve 2018 yllında 6701 sayllı Kanunun 8. maddesine "Cumhurbaşkaninin görevlendireceği bakan ile ilişkili" ifadesi getirilmiştir²3. Yapılan bu değiş̧iklik ile Kurumun yönetimine ilişkin yetkilerin Cumhurbaşkanı’nın gerekli gördüğü durumlarda bakan vasıtasıyla kullanılabileceği hüküm altına alınmışı ${ }^{24}$.

Yapısı giderek sağlamlaşan ve güçlenen TİHEK, Cumhurbaşkanı’nın görevlendireceği bakan ile ilişkili bir kurum olarak varlığını sürdürmektedir. İnsan haklarının korunması ve geliştirilmesi, ayrımcılık ile mücadele edilerek eşitliğin sağlanması ve işkence ile kötü muameleye karşı mücadele de bulunacak olan TİHEK, belirttiğimiz bu fonksiyonları tek çatı altında kendi bünyesinde toplamışıır ${ }^{25}$. Bu faaliyetler kapsamında TİEHK hem kamu hem de özel kesimin eğitiminin yanı sıra, kamu ve özel kesim üzerinde inceleme, gözetim ve yaptırım uygulama yetki ve görevlerine sahiptir ${ }^{26}$.

18 Düğmeci, s.237.

1929690 sayı ve 20.04.2016 tarihli Resmi Gazete'de yayımlanan 6701 sayı ve 06.04.2016 kabul tarihli Türkiye İnsan Hakları ve Eşitlik Kurumu Kanunu’nun 28. maddesi kapsamında 6332 sayı ve 21.06.2012 kabul tarihli Türkiye İnsan Hakları Kurumu Kanunu yürürlükten kaldırılış ve TİHK’nun tüzel kişiliği sona erdirilmiştir.

20 Odyakmaz / Keskin / Deniz, s.732.

21 Şükrü Altıntaş, Türkiye’de İnsan Haklarının Gelişimi ve Kurumsal Yapılanması: İnsan Hakları ve Eşitlik Kurumu Örneği, Karamanoğlu Mehmetbey Üniversitesi Sosyal Bilimler Enstitüsü yayımlanmamış Yüksek Lisans Tezi, Karaman, 2019, s.95.

22 Altıntaş, s.95.

2330437 sayı ve 09.07.2018 tarihli Resmi Gazete'de yayımlanan 703 sayı ve 02.07.2018 kabul tarihli Anayasada Yapılan Değișikliklere Uyum Sağlanması Amacıyla Bazı Kanun ve Kanun Hükmünde Kararnamelerde Değişiklik Yapılması Hakkında Kanun Hükmünde Kararname’nin 149. maddesi ile TİHEK’in Başbakanlık ile ilişkisi ortadan kaldırılmıştır.

24 Mehmet Akad / Bihterin Vural Dinçkol / Nihat Bulut, Genel Kamu Hukuku, Gözden Geçirilmiş 16. Basım, Der Yayınevi, İstanbul, 2020, s.360.

25 Odyakmaz / Keskin / Deniz, s.733; Altıntaş, s.96.

26 Güneş, s.174. 


\section{B. TÜRKIYE INSAN HAKLARI VE EŞITLIK KURUMU'NUN HUKUKi NITELIĞi VE IDARI TEŞKILAT IÇINDEKI YERI}

06.04.2016 tarih ve 6701 sayılı Türkiye İnsan Hakları ve Eşitlik Kurumu Kanunu ile kurulan TİHEK, kamu tüzel kişiliğini haiz, idari ve mali özerkliğe sahip, özel bütçeli bir kurum olarak idari teşkilat içerisinde kendisine yer bulmuştur. Kurum, 6701 sayılı Kanun ile yeni bir çehreye kavuşmuştur. 2012 yılında 6332 sayılı mülga Kanun ile sahip olmadığı yeni yetkiler ile çeşitli kamusal güçlere sahip olmasıyla, kamu kurumu niteliğinde de çeşitli değişimler ortaya çıkmıştır.

TİHEK'in, 6701 sayılı Kanun ile kurulan bir kamu tüzel kişiliği olması sebebiyle idari teşkilat içindeki yerinin tam olarak tespit edilmesi de gereklidir. Ulusal kapsamda insan haklarının korunması bakımından TİHEK’in yürüttüğü faaliyet, idari teşkilatta yer alan diğer kamu kurumlarının ortaya çıkardığ kamu hizmetlerinden farklı boyuta sahiptir ${ }^{27}$. Özellikle ayrımcı eylemlerin sona erdirilebilmesi bağlamında kamu düzenini sağlamaya çalışan TİHEK’in bu anlamda klasik bir kamu kurumu olmadığ 1 da söylenebilir ${ }^{28}$.

Kurumun özerkliğe sahip olması bakımından 6701 sayılı Kanun'un açıkça kullandığı ifadeler, TİHEK'in merkezi idareden ayrılarak karar alma süreci gibi birçok konuda faaliyet alanına uygun bir şekilde hareket edebilme özgürlügünü elinde bulundurmasını sağlamıştır. İnsan haklarının korunması bağlamında ulusal ve uluslararası koruma mekanizmaları arasında bir köprü olabilmesi adına bu özerkliğin tanınması gerekliliği kaçınılmaz olmaktadır ${ }^{29}$. TİHEK’in bütçesinin TBMM tarafından belirlenerek merkezi bütçeden ayrı bir yapıya sahip olması, harcama takdir yetkisini bağımsızca elinde bulundurmasını sağlamaktadır. İdari özerkliğin tanınması ile de kurum personelinin, ihtiyaca uygun donanımlı kişiler arasından liyakat esası ile seçilebilmesi sağlanmıştır. Personel seçimi bakımından ayrıca herhangi bir makamdan onay alınma gereği olmaması da, TİHEK’e sunulan idari özerkliğin kuvvetini göstermektedir ${ }^{30}$.

İdari özerklik bakımından 6332 sayılı mülga Kanun ile 6701 sayılı Kanun kapsamında TİHEK'in ilişkili olduğu idari birimin değişimi de ayrıca görülmektedir. Başbakanlık ile doğrudan ilişkili olan Kurumun, 6701 sayılı Kanun kapsamında Cumhurbaşkanı’nın belirleyeceği bakanlık ile ilişkisi olacağını belirtmiştik. 2018/1 sayılı Cumhurbaşkanlığı Genelgesi’nin Ek-1 Listesi uyarınca TİHEK, Adalet Bakanlığı ile ilişkilendirilmiştir ${ }^{31}$. Dolayısıyla sistem değişikliği sonrasında Kurumun artık başbakanlık yerine bakanlık nezdinde merkezi idare ile ilişkisi devam edecektir. TİHEK’in ilişkili bir kurum olması, 6701 sayılı Kanunun 8. maddesinde yer alan idari özerkliğe sahip olması niteliğini kuvvetlendirmektedir. Hiyerarşik bir üstünün bulunmaması kamu tüzel kişiliği niteliğinin en temel özelliklerinden birisidir. Ancak bu husus, TİHEK’in idari bir denetime tabi olmadığı anlamına

27 Halil Kalabalık, İnsan Hakları Hukuku, 5. Baskı, Seçkin Yayınevi, Ankara, 2017, s.345.

28 Düğmeci, s.240.

29 Kalabalık, s.345.

30 Hayrettin Eren, Türkiye İnsan Hakları ve Eşitlik Kurumu, 1. Baskı, Adalet Yayınevi, Ankara, 2016, s.96.

3130479 sayı ve 15.07.2018 tarihli Resmi Gazete’de yayımlanan Bakanlıklara Bağlı, İlgili ve İlişkili Kurum ve Kuruluşlar ile İlgili 2018/1 Sayılı Cumhurbaşkanlığı Genelgesi. 
gelmemektedir $^{32}$. İdari denetim, idari vesayet yetkisinin kullanımı ile gerçekleşmektedir. Merkezden yönetimin yerinden yönetim kurumları bakımından idari vesayet denetimi kapsamında idarenin bütünlüğü ilkesini tamamladıklarını ağırlıkla belirtmemiz gerekmektedir ${ }^{33}$. Bu nedenle yerel yönetim idaresi olmayan ancak kamu kurumu olarak düzenlenen TİHEK’in, merkezi idarenin idari vesayet denetim yetkisi altında tutulabileceğini belirtebiliriz. 6701 sayılı Kanun'da açıkça merkezi idarenin idari vesayet yetkisini tanıdığı yetkiler bakımından bu denetim sistemi işleyecektir ${ }^{34}$.

TİHEK'in kamu kurumu sinıflandırılması anlamında da incelemesi gerekmektedir. Mevzuat, doktrin ve yargı kararları bağlamında TİHEK'in özellikle düzenleyici ve denetleyici kurumlar arasında yer aldığ düşünülmektedir ${ }^{35}$. Bu kapsamda düzenleyici ve denetleyici kurum niteliğine ne şekilde sahip olduğunu gözlemlemek, Kurumun yürüteceği faaliyetin belirlenmesi açısından da yol gösterici olacaktır.

Doktrinde düzenleyici ve denetleyici kurumlar bakımından bir alt sınıflandırma yapılabileceği de belirtilmektedir. Bu sınıflandırma doktrinde üçlü bir sistematik ile ifade edilmektedir ki, bunlar, "piyasa ekonomisinin düzenlenmesine ilişkin kurumlar", "temel hak ve özgürlüklerin korunmasını amaçlayan kurumlar" ve "idarenin keyfiliğine veya bürokrasiye karşı bireyin korunmasını amaçlayan kurumlar"dır ${ }^{36}$. Bu doğrultuda TİHEK'in faaliyet alanı bakımından temel hak ve özgürlüklerin güvence altına alınması konusunda idari işlemler tesis etmesi nedeniyle, düzenleyici ve denetleyici kurum olarak nitelendirilmesi yerinde olacaktır. Temel hak ve özgürlüklerin korunması bakımından sadece kamu idareleri ve kamu kurumları karşısında değil, özel hukuk kişilerinin de özellikle ayrımcılık yasağını ihlal etmemesi için idari işlem tesis edebilme yetkisine sahip olan TİHEK’in bu yönüyle ilk grup yerine üçüncü grupta değerlendirmek daha doğrudur.

TİHEK, ilk bakışta her ne kadar temel hak ve özgürlüklerin korunmasını sağlama faaliyetini yürütmesi nedeniyle düzenleyici ve denetleyici kurum olarak yorumlansa da Kurumun niteliği

32 Düğmeci, s.244.

33 Merkezden yönetimin sadece yerel yönetimler üzerinde değil, geri kalan yerinden yönetim kamu tüzel kişileri üzerinde de idari vesayet yetkisini kullandığına dair doktrindeki ağırlıklı görüş için bakınız; Turan Yıldırım / Melikşah Yasin / Nur Kaman / H. Eyüp Özdemir / Gül Üstün / Özge Okay Tekinsoy, İdare Hukuku, Güncelleştirilmiş 7. Baskı, Oniki Levha Yayıncılık, İstanbul, Ekim 2018, s.30; Bahtiyar Akyılmaz / Murat Sezginer / Cemil Kaya, Türk İdare Hukuku,12. Baskı, Savaş Yayınevi, Ankara, Eylül 2020, s.185; Ali D. Ulusoy, Yeni Türk İdare Hukuku, Gözden Geçirilmiş 3. Baskı, Yetkin Yayınları, Ankara, 2020, s.150; Kemal Gözler, İdare Hukuku Cilt: I, 2. Baskı, Ekin Basın Yayın Dağıtım, Bursa, 2009 , s.209.

34 Eren, Türkiye İnsan Hakları ve Eşitlik Kurumu, s.83.

35 Düzenleyici ve denetleyici kurum, bakımından kimi farklılıklara rağmen "Bağımsız İdari Otoriteler" kavramı da doktrinde ayrıca yaygın kullanıma sahiptir; Ali Ulusoy, Bağımsız İdari Otoriteler, Turhan Kitabevi, Ankara, 2003, s.6; Turgut Tan, "Bağımsız İdari Otoriteler veya Düzenleyici Kurullar”, Amme İdaresi Dergisi, Cilt: 35, Sayı: 2, Haziran 2002, s.11; Müslüm Akıncı, Bağımsız İdari Otoriteler ve Ombudsman, Beta Yayınları, İstanbul, 1999, s.375; Ender Ethem Atay, "Bağımsız İdari Otoriteler ve Türkiye Uygulaması", Gazi Üniversitesi Hukuk Fakültesi Dergisi, Cilt: 10, Sayı: 1-2, 2006, s.259-293; Emrah Uran, Türkiye'deki Bağımsız İdari Otoritelerin İdari Yaptırım Yetkisi, 1. Baskı, Oniki Levha Yayıncılık, İstanbul, Ağustos 2012, s.53; D. Çiğdem Sever, “Türkiyede Düzenleyici kurumların Yapısl, İşlevi ve Dönüşümü”, Ankara Üniversitesi Hukuk Fakültesi Dergisi, Cilt: 64, Sayı:1, 2015, s.196; Turan Yıldırım, “Bağımsız İdari Otoritelerin Yargısal Denetimi”, 2000 Yılı İdari Yargı Sempozyumu, Danıştay Yayını, No: 59, 2000, s.201.

36 F. Gazier et Y. Cannal, “Etudes sur les autorités administratives indépendantes”, EDCE, No.35, s.18'den aktaran Turgut Tan, Ekonomik Kamu Hukuku, Turhan Kitabevi, Ankara, Şubat 2010, s.192; Atay, "Bağımsız İdari Otoriteler ve Türkiye Uygulamasi”, s.263; Uran, s.53. 
fonksiyonel görevleri bakımından hem yargı kararlarında hem de doktrinde tartışma konusu olmuştur. TİHK’in kurucu kanunu olan 6332 sayılı Türkiye İnsan Hakları Kurumu Kanunu’nun kimi hükümlerinin Anayasa'ya aykırı olduğu iddiası ile açılan iptal davasında Anayasa Mahkemesi, ulusal anlamda insan haklarının korunması faaliyeti yürüten kurumlara ilişkin olarak genel açıklamada bulunmuştur;

“... Kanun'un 3. maddesinde, İnsan Hakları Kurumunun kamu tüzel kişiliğini haiz, idari ve mali özerkliğe sahip, özel bütçeli ve Başbakanlıkla ilişkili olduğu belirtilmek suretiyle, Kurumun kendisine verilen görevleri bağımsız bir şekilde yerine getirmesinin amaçlandığ anlaşılmaktadır. Türk idari teşkilatı içinde yer alan ilişkili kuruluşlar, kamudaki bazı alanları düzenlemek ve korumak amacıla kurulan, kamu tüzel kişiliğine sahip, kararları hiyerarşik açıdan denetime tabi olmayan, üyeleri bağımsız, yönetimleri idari ve mali açıdan özerk olan kuruluşlardır. Bu kuruluşların Ülkemiz için tipik örneği bağımsız idari otoritelerdir" 37 .

Karardan da anlaşılacağı üzere Anayasa Mahkemesi, TİHK’in düzenleyici ve denetleyici kurum olduğu düşüncesini, "bağımsız idari otorite” terimini kullanarak ifade etmiştir. Kararda özellikle Kurumun hiyerarşik bir denetim altında olmadığı ve bağımsız bir karar alma yetkisine sahip olması üzerinde duran Anayasa Mahkemesi, bu özelliğin düzenleyici ve denetleyici kurumların temel özelliği olduğunu belirtmektedir. Temel olarak ulusal insan haklarını koruma faaliyetini yerine getiren kurumların özerk olma gerekliliği, kurumların bağımsız şekilde karar alabilmesi için kaçınılmaz bir özelliktir ${ }^{38}$. TİHEK’in aynı özelliğe sahip olması sebebiyle, Anayasa Mahkemesi'nin TİHK hakkında ifade ettiği görüşün, TİHEK için de geçerli olduğunu kabul edebiliriz.

Doktrinde TİHEK’in düzenleyici ve denetleyici kurum olarak değerlendirilip değerlendirilmemesi bakımından farklı görüşler bulunmaktadır. Anayasa Mahkemesi’nin görüşü yönünde ifade edilen düşüncelerde ağırlıkla, TİHEK’in idari teşkilatta düzenleyici ve denetleyici kurum olduğu belirtilmektedir. TİHEK’in, kamu tüzel kişiliği, idari ve mali özerkliğe sahip oluşu ve özel bütçesinin bulunması kapsamında düzenleyici ve denetleyici kurum sınıflandırması içerisinde yer alması gerektiği vurgulanmaktadır ${ }^{39}$.

Doktrinde aksi yönde görüşler de bulunmaktadır. TİHEK, Kamu Denetçiliği Kurumu (KDK) gibi atipik bir yapıya sahiptir ${ }^{40}$. Ne mahalli idare ne de bir hizmet yönünden yerinden yönetim kurumu olmadığı belirtilen TİHEK’in, düzenleyici ve denetleyici kurumlara da tam olarak benzemediği ifade edilmektedir ${ }^{41}$. Başka bir görüş ise TİHEK'in halefi olan TİHK ile KDK’nın düzenleyici ve

3728868 sayı ve 31.12.2013 tarihli Resmi Gazete'de yayınlanan Anayasa Mahkemesi'nin E.2012/98, K.2013/92 sayı ve 17.07.2013 tarihli kararı.

38 Odyakmaz / Keskin / Deniz, s.734.

39 Kalabalık, s.345.

40 Eren, Türkiye İnsan Hakları ve Eşitlik Kurumu, s.84.

41 Eren, Türkiye İnsan Hakları ve Eşitlik Kurumu, s.84. 
denetleyici kurumlardan farklı bir niteliğe sahip olduğunu belirtmiştir ${ }^{42}$. Bu kurumların esas olarak danışma, rapor hazırlama, tavsiye kararları gibi bağlayıcı ve icrai olmayan yetkiler kullanması nedeniyle düzenleyici ve denetleyici kurum yerine insan haklarının korunmasına yardımcı olacak kurumlar olarak değerlendirilmesi gerektiği ifade edilmektedir ${ }^{43}$. Ancak THİK’ten THİK’e geçiş sürecinde elinde bulundurduğu belirtilen yetkilerin yanı sıra, bağlayıcı etkiye sahip olan idari yaptırım yetkisinin de kazanılmasıyla bu durumun değiş̧tği söylenebilir.

Bağlayıcı karar alma yetkisine sahip olunup olunmaması yönünden Kurum’da değişim yaşanmıştır. TİHK'ten TİHEK’e geçiş sürecinde Kurumun bağlayıcı bir karar alma yetkisine kavuşması söz konusu olmuştur $^{44}$. 6701 sayılı Kanun ile TİHEK, halefi olan TİHK’in sahip olmadığı bir idari yaptırım yetkisine kavuşmuştur. İnsan haklarının korunması ve geliştirilmesi ödevlerinin yanı sıra Kurum, ayrımclık yasağı ihlalleri kapsamında 6701 sayılı Kanun’un 25. maddesi uyarınca, bağlayıcı bir idari yaptırım kararı alma yetkisine sahip olmuştur ${ }^{45}$. TİHK'in tavsiye ve görüş bildirme fonksiyonuna ek olarak TİHEK'te bağlayıcı karar alabilme fonksiyonunun getirilmesi, insan hakları ihlallerinin engellenmesi yolunda etkili olabilecek bir araç olarak düşünülebilmektedir. Aslında TİHEK’in diğer düzenleyici ve denetleyici kurumlar gibi toplum yaşamının duyarlı alanlarında yaptırımlar uygulaması hususu, Kurumun genel fonksiyonunu da göstermektedir. Bu kapsamda doğrudan icrai niteliğe ve güce sahip olan kurumların yargısal ve idari denetime tabi olacağı da kaçınılmazdır ${ }^{46}$. TİHEK'in idari yaptırım anlamında icrai karar alma yetkisine sahip olması, düzenleyici ve denetleyici bir kurum olma niteliğinin sağlamlaştığını göstermektedir ${ }^{47}$.

Düzenleyici ve denetleyici kurumların her birinin ayrı kanun ya da Cumhurbaşkanlığı Kararnamesi ile düzenlenmesi, mevzuat anlamında doğrudan bir yasal tanıma sahip olamamalarına neden olmuştur $^{48}$. Bu kapsamda dolaylı yoldan listeleme çabası gösteren tek mevzuat, 5018 sayılı Kamu Malî Yönetimi ve Kontrol Kanunu’nda yer alan cetveldirr ${ }^{49}$. "Düzenleyici ve Denetleyici Kurumlar" başlıklı III Sayılı Cetvel yerine TİHEK, II Sayılı Cetvel başlığında yer alan "Özel Bütçeli Diğer İdareler” arasında sayılmıştır. Anayasa Mahkemesi ve doktrin görüşleri ile 5018 sayılı Kanun arasında, TİHEK’in niteliğine ilişkin incelemede farklılı̆̆ın ortaya çıktığı görülmektedir. Yasal düzlem ile yargı kararları ve doktrinin aynı doğruda gidecek şekilde kurumun niteliğinin tekrar ele alınması, görüş birliğinin sağlanması açısından faydalı olacaktır.

42 Sever, s.216-217.

43 Sever, s.217.

44 Odyakmaz / Keskin / Deniz, s.731.

456701 sayılı Kanunun 25. maddesi uyarınca; “Ayrımcılık yasağının ihlali hâlinde, bu ihlalin etki ve sonuçlarının ağırlı̆̆ı, failin ekonomik durumu ve çoklu ayrımcılĭğn ağırlaştırıcı etkisi dikkate alınarak ihlalden sorumlu olan kamu kurum ve kuruluşları, kamu kurumu niteliğindeki meslek kuruluşları, gerçek kişiler ve özel hukuk tüzel kişileri hakkında bin Türk lirasından on beş bin Türk lirasına kadar idari para cezası uygulanır".

46 Hasan Nuri Yaşar / S. Sena Cabığlu Güler, "Düzenleyici ve Denetleyici Kurumların Yetkileri Kapsamında Kamu Gücü İlişkisi”, Gazi Üniversitesi Hukuk Fakültesi Dergisi, Cilt: XX, Sayı:4, 2016, s.73.

47 Düğmeci, s.242.

48 Sever, s.197.

4925326 sayı ve 24.12.2003 tarihli Resmi Gazete’de yayımlanan 5018 sayı ve 10.12.2003 kabul tarihli Kamu Malî Yönetimi ve Kontrol Kanunu. 


\section{TÜRKIYE INSAN hAKLARI VE EşitLiK KURUMU'NUN KAMU DENETÇILIĞi KURUMU'NDAN FARKLILIĞI}

İnsan haklarının korunması ve ayrımcılığın engellenmesi adına ulusal anlamda faaliyette bulunan tek kurum TİHEK değildir. Yargı dışı hukuksal başvurular içinde idari başvurular çeşitliliğe sahiptir. $\mathrm{Bu}$ anlamında farklı kamu kurumlarının insan hakkı ihlallerini denetlediği görülmektedir. TİHEK dışında bu görevi üstlenen diğer kurum Kamu Denetçiliği Kurumu (KDK)dur.

TİHEK ile insan haklarının korunması bakımından aynı doğrultuda hareket eden KDK, fonksiyonel ve içeriksel anlamda ise farklılı̆a sahiptir. 6328 sayılı Kamu Denetçiliği Kurumu Kanunu’nda KDK’nın temel amacı, "kamu hizmetlerinin işleyişsinde bağımsız ve etkin bir şikâyet mekanizması oluşturmak suretiyle, idarenin her türlü eylem ve işlemleri ile tutum ve davranışlarını; insan haklarına dayalı adalet anlayışı içinde, hukuka ve hakkaniyete uygunluk yönlerinden incelemek, araştrrmak ve önerilerde bulunmak" olarak belirtilmiştir ${ }^{50}$. Bu ifade kapsamında, KDK tarafından alınan kararların konusunun içeriği ile fonksiyonel sonuçları yönüyle TïHEK’ten farkllığa sahip olduğu görülmektedir. Bu bağlamda TïHEK ile KDK arasındaki farklıları, yaptıkları incelemelerin içeriği, aldıkları kararların fonksiyonel sonuçları üzerinden inceleyebiliriz. Bu iki farklılı̆a ek olarak TïHEK ve KDK’nın ilişkili oldukları teşkilat bakımından da inceleme yapmak, kurumlar arasındaki temel çizgilerin belirlenmesini sağlayacaktır.

Öncelikle TİHEK ile KDK’nın yürüttükleri idari faaliyetlerin amaçları arasındaki temel farklılıklar göze çarpmaktadır. 6328 sayılı Kanun’un 1. maddesi kapsamında KDK’nın, idarelerin faaliyetlerinde ilgililere karşı hakkaniyetli ve hukuka uygun davranmaları yönünde inceleme yapmak ile görevlendirildiği açıktır ${ }^{51}$. Bu doğrultuda idarelerin faaliyetlerinde iyi yönetim ilkesine daha sıkı sarılmaları amaçlanmaktadır. Bir diğer amaç ise, idari yargı yoluna başvurulmadan da ortaya çıan uyuşmazlıkların çözümlenmesi için arabuluculuk yükümlülüğünü sağlamaktır ${ }^{52}$. Dolayısıyla idari faaliyetten etkilenenler ile idare arasından bir dostane çözüm sağlanarak emsaller de yaratılacaktır. Bu anlaşmazlıkların çözümünde hız kazanılması ve bu sayede idari yargının yükünün hafifletilmesi de sağlanabilecektir ${ }^{53}$. Bu kapsamda sadece idarelerin idari faaliyetleri üzerinde karar alabilme yetkisine sahip olan KDK, TİHEK’ten inceleme yaptıkları alanlar bakımından ayrışmaktadır. KDK, özellikle kamu yönetimi ile kamu görevlilerinin keyfi, hatalı ve hukuka aykırı işlem ve eylemlerinden doğan ihtilafları denetleme yetkisine sahiptir ${ }^{54}$. Buna karşın TİHEK'in sadece kamu idareleri, kamu kurumları ve kamu hizmeti yürüten özel hukuk tüzel kişileri değil, insan haklarını ve ayrımclık yasağını ihlal eden her gerçek ve tüzel kişiler üzerinde denetim yetkisi bulunmaktadır. Bu denetimi yaparken ulusal önleme mekanizması görevini yerine getirmek ile 6701 sayılı Kanun'un 1. maddesi kapsamında yetkilendirildiği açıktır.

5028338 sayı ve 29.6.2012 tarihli Resmi Gazetede yayımlanan 6328 sayı ve 14.06.2012 kabul tarihli Kamu Denetçiliği Kurumu Kanunu'nun "Amaç" başlıklı 1 maddesi.

51 Odyakmaz / Keskin / Deniz, s.735.

52 Düğmeci, s.230.

53 Zehra Odyakmaz, "Kamu Denetçiliği (Ombudsmanlık) Kurumunun Tantılması ve 6328 Sayılı Kanunun Bazı Maddelerinin Değerlendirilmesi”, Türkiye Adalet Akademisi Dergisi, Cilt: 4, Sayı: 14, 2013, s.21.

54 Tülin Çağdaş, "Ombudsman Kurumu ve Türkiye’de 6328 Sayılı "Kamu Denetçiliği Kurumu Kanunu”nun Düzenlenmesi”, İstanbul Medipol Üniversitesi Hukuk Fakültesi Dergisi, Cilt: 4, Sayı: 2, Güz 2017, s.92. 
İnsan haklarının korunması, geliştirilmesi ve ayrımcılığın engellenmesi bakımından idari yaptırım uygulayabilme yetkisine sahip olan TİHEK'in KDK'dan farklılaşan bir diğer özelliği de fonksiyonları konusunda ortaya çıkmaktadır. KDK, sadece kendisine ulaşan "şikâyet" üzerine harekete geçebilen bir kurum olarak görev yapmaktadır. Bu kapsamda somut olaylara resen yaklaşamadığ 1 görülmektedir ${ }^{55}$. Diğer ulusal kamu denetçiliği kurumlarından farklı olarak KDK, şikâyet olmaksızın idarenin işlem ve eylemlerinde gördüğü aksaklıkları kendiliğinden inceleyememektedir ${ }^{56}$. Kamu Denetçiliği Kurumu Kanunu’nun Uygulanmasına İlişkin Usul ve Esaslar Hakkında Yönetmeliğin 7. maddesi uyarınca şikâyet hakkına sadece menfaati ihlal edilenlerin sahip olabileceği belirtilmiş, fakat şikâyet konusunun temel hak ve özgürlüklere yönelik olması ya da kamuoyunu ilgilendirmesi durumunda şikâyetin yapılmasında menfaat ihlalinin aranmayacağı hüküm altına alınmıştır ${ }^{57}$. Menfaat ihlalinin aranmaması kapsamında getirilen istisnai durumun yerinde olduğu da doktrinde benimsenmektedir ${ }^{58}$. Şikâyetin menfaat ile sınırlandırılmayacağı hallerin bulunmasına rağmen düzenlemeden de açıkça anlaşlacağ 1 üzere, KDK ihlallerin incelenmesi yönünde resen harekete geçemeyecektir. Doktrindeki görüşler bağlamında KDK’nın resen inceleme yetkisine sahip olmamasının sebebinin, KDK’nın aşırı iş yükü altında ezilerek ana faaliyet konusunu yerine getiremeyeceği düşüncesi olduğu belirtilmektedir ${ }^{59}$.

TİHEK'in somut olayları inceleyebilmesi bakımından yetkiye sahip olmasında KDK'dan ayrıştığı nokta, mevzuat kapsamında da tespit edilebilmektedir. Türkiye İnsan Hakları ve Eşitlik Kurumu tarafından yürürlüğe konmuş olan Türkiye İnsan Hakları ve Eşitlik Kurumu Kanununun Uygulanmasına İlişkin Usul ve Esaslar Hakkında Yönetmeliğin 24/I. maddesinin "f” ve "g" bentleri uyarınca TIHEK, insan hakları ihlali ve ayrımcılık yasağı ihlali iddialarını incelemeyi, sadece kendisine yapılacak başvurular üzerinden değil, resen de yapabilmektedir ${ }^{60}$.

TİHEK ile KDK arasındaki fonksiyonel ayrımın tespit edilebilmesi için alınan kararların bağlayıcılık etkeni de göz önünde bulundurulmalıdır. KDK kararlarının niteliğinin incelemesinde karşımıza 6328 sayılı Kanunun 5. maddesinin ilk fikrası çıkmaktadır. Hüküm uyarınca; "Kurum, idarenin işleyişi ile ilgili şikâyet üzerine, idarenin her türlü eylem ve işlemleri ile tutum ve davranışlarmi; insan haklarına dayalı adalet anlayışı içinde, hukuka ve hakkaniyete uygunluk yönlerinden incelemek, araştırmak ve idareye önerilerde bulunmakla görevlidir". Hükümden de anlaşılacağı üzere Kurumun yükümlülüğünün, kendisine sunulan şikayetler üzerine önerilerde bulunmak olduğu açıktır. Bu doğrultuda KDK’nın yapmış olduğu incelemeler sonucunda aldığı kararların tavsiye niteliğinde olduğunu ve bağlayıcı özelliklerinin olmadığını belirtmek gerekir ${ }^{61}$. KDK bu yetki ile mevcut

Düğmeci, s.232.

Ender Ethem Atay, “Hukuk Devleti İlkesi Işı̆̆ında İdarenin Denetimi ve Kamu Denetçiliği”, Ombudsman Akademik Dergisi, Sayı: 1, 2014, s.28.

28601 sayı ve 28.03.2013 tarihli Mükerrer Resmi Gazete’de yayımlanan Kamu Denetçiliği Kurumu Kanununun Uygulanmasına İlişkin Usul ve Esaslar Hakkında Yönetmelik.

Mehmet Yüce / Atanur Beyce, Kamu Denetçiliği Hukuku, Savaş Yayınevi, Ankara, Kasım 2013, s.60; Düğmeci, s.232.

Odyakmaz, s.34.

30250 sayı ve 24.11.2017 tarihli Resmi Gazete’de yayımlanan Türkiye İnsan Hakları ve Eşitlik Kurumu Kanununun Uygulanmasına İlişkin Usul ve Esaslar Hakkında Yönetmelik.

Odyakmaz, s.7; Çağdaş, s.102. 
yönetimi iyileştirme amacıyla önerilerde bulunur ${ }^{62}$. Bu öneriler kapsamında yerindelik bakımından da değerlendirmeler yapabilen KDK, idari işlemi tesis etmiş olan ilgili idareden, idari faaliyet kapsamındaki bu idari işlemin geri alınmasını veya kaldırılmasını talep edebilmektedir ${ }^{63}$. TİHEK bakımından ise bağlayıcı karar alabilme yetkisi konusunda KDK'dan farklılık ortaya çıkmaktadır. 6701 sayılı Kanun’un 9, 11 ve 25. maddelerinde açıkça belirtildiği üzere, ayrımcılık yasağını ihlal edenler hakkında idari yaptırım kararının alınabilmesi, TIHHEK'i KDK'dan ayırmaktadır. TİHEK'in yaptı̆̆ı inceleme sonucunda doğrudan ilgililer üzerinde bağlayıcı bir etki doğuran idari yaptırım yetkisinin bulunması, bu kapsamda alacağı kararların yargı denetimine tabi olmasını ayrıca gerektirmektedir.

KDK, 6328 Sayılı Kanun’un 4. maddesinde açıkça ifade edildiği üzere Türkiye Büyük Millet Meclisi Başkanlığı’na bağlı bir kurum olarak kurulmuştur. İdari teşkilatlanma bakımından ayrık bir yapıya sahip olan KDK’nın ilişkili olduğu birim bakımından da farklılığı ortaya çıkmaktadır. Yasama erki ile bağı, KDK’nın klasik kamu kurumlarından kendisini ayırır. Öte yandan 6701 sayılı Kanun'un 8. maddesi kapsamında Cumhurbaşkanlığının görevlendirdiği Adalet Bakanlığı ile ilişkili olması, TİHEK'in KDK'dan farklılı̆̆ını bir kez daha gözler önüne sermektedir.

\section{TÜRKIYE INSAN HAKLARI VE EŞitLIK KURULU'NUN KURUM IÇINDEKi YERI VE FONKSIYONU}

TİHEK kendi içerisinde çeşitli idari birimlere bölünmektedir. 6701 sayılı Kanun sistematiği ile Türkiye İnsan Hakları ve Eşitlik Kurulu, Başkanlık ile Başkanlığa bağlı hizmet birimleri ve çalışma guruplarından oluşur.

Türkiye İnsan Hakları ve Eşitlik Kurulu (Kurul), Kurum içinde Kurumun faaliyet alanına ilişkin karar alma yetkisine sahip olması sebebiyle çalışmamızın esasında yer alan idari birimdir. 6701 sayılı Kanun'un 10. maddesiyle ve Kurumun karar organı olarak düzenlenen Kurul, kendisine kanun ve mevzuatla verilen görev ve yetkileri yerine getirirken sorumluluğa sahip olan bağımsız bir organdir ${ }^{64}$.

Kurul'un yapısı başkan, ikinci başkan ve 9 üyeden oluşmaktadır. 6701 sayılı Kanunun 10. maddesi uyarınca 11 üyenin tamamı Cumhurbaşkanı tarafından atanmaktadır. Yine 6701 sayılı Kanun’un 10/ IV. maddesinde atanacak üyelerde aranacak nitelikler belirtilmiştir. Burada önemli bir husus, üye olarak atanacak kişilerde aranan niteliklerde, Üst Kademe Kamu Yöneticileri ile Kamu Kurum ve Kurullarında Atama Usullerine Dair 3 Sayılı Cumhurbaşkanlığı Kararnamesi ile 6701 sayılı Kanun arasında farklılığın bulunmasıdır ${ }^{65}$. Bu farklılıklar bakımından üye seçiminde hangi hükümlerin

62 Kalabalık, s.366.

63 İbrahim Keskin, "Temel İnsan Hakları Bağlamında Ombudsmanlık Kurumunun Hukuku Devletindeki Yeri ve Önemi”, Adalet Dergisi, Sayı: 45, 2013, s.130.

64 Kalabalık, s.347.

6530474 sayı ve 10.07.2018 tarihli Resmi Gazete’de yayımlanan Üst Kademe Kamu Yöneticileri ile Kamu Kurum ve Kuruluşlarında Atama Usullerine Dair 3 Sayılı Cumhurbaşkanlığı Kararnamesi. 
uygulanacağı tartışmasına ilişkin olarak Anayasa’nın 107 / XVII. maddesi kapsamında, 6701 sayılı Kanun hükümlerinde yer alan niteliklerin uygulanması gerektiğini belirtmemiz gerekir. Anayasa 107 / XVII. maddesi uyarınca; "Cumhurbaşkanlı̆̆ı kararnamesiyle kanunlarda farklı hükümler bulunması halinde, kanun hükümleri uygulanır” ifadesi ile 6701 sayılı Kanunun uygulanabilirliği hakkında yorum kuvvetlenmektedir ${ }^{66}$.

Kurul faaliyetlerini yürütürken hiçbir makam, merci ya da kişiden emir ve talimat almadan bağımsız bir şekilde karar alacaktır ${ }^{67}$. Tabi bu bağımsızlı̆̆ın sağlanabilmesi amacıyla 6701 sayılı Kanun, üyeleri bazı yükümlükler vermiştir. 6701 sayılı Kanun’un 10 / IX. maddesi uyarınca;

"Üyelerin Kurulda görev yaptıkları sürece önceki görevleri ile olan ilişikleri kesilir. Üyeler, özel bir kanuna dayanmadıkça, Kuruldaki görevlerinin dışında resmî veya özel hiçbir görev alamaz, dernek, vakıf, kooperatif ve benzeri yerlerde yöneticilik ve denetçilik yapamaz, ticaretle uğraşamaz, serbest meslek faaliyetinde bulunamaz, hakemlik ve bilirkişilik yapamaz. Ancak üyeler, asli görevlerini aksatmayacak şekilde bilimsel amaçl yayın yapabilir, ders ve konferans verebilir ve bunlardan doğacak telif hakları ile ders ve konferans ücretlerini alabilir."

Bu kapsamda üyelerin, üyelik görevlerinden doğan faaliyetleri aksatmayacak şekilde yapacakları bilimsel çalışmalar ayrık kalmak üzere, birçok görevlerinden ayrılmaları gerekecektir.

Kurul'un, Kurumun faaliyet alanıyla ve Kurumun iç işleyişine ilişkin birçok kararı alabilme görevi ve yetkisi bulunmaktadır. TİHEK’in kurulma amaçlarından en önemlisi olan ayrımcılık yasağının ihlali kapsamında idari yaptırım yetkisi uygulama yetkisi, Kurul’a verilmiş en önemli yetkilerden biridir ${ }^{68}$. Çalışmamızın üzerinde durduğu esas alan olarak bu idari yaptırım yetkisinin kullanılmasında 6701 sayılı Kanun, Kurul'un inceleme ve araştırma yapabilmesi için gerekli yetki ve araçları sağlamaktadır. Özellikle 11 / I-a. maddesi uyarınca; "Kurumla ve Kurumun görev alanıyla ilgili düzenlemeler yapılmasına yönelik kararlar almak” hükmü ile Anayasa 124. madde ile kamu tüzel kişiliklerine tanınan yönetmelik düzenleme yetkisinin Kurul’a sağlandığını belirtmek yanlış olmayacaktır ${ }^{69}$. Bu kapsamda özellikle 6701 sayılı Kanunun uygulanabilmesi adına TİHEK tarafından Türkiye İnsan Hakları ve Eşitlik Kurumu Kanunun Uygulanmasına İlişkin Usul ve Esaslar Hakkında Yönetmelik yayımlanmıştır. Hem 6701 sayılı Kanun hem de Yönetmelik, Kurul'un idari yaptırım kararı alabilmesi bakımından düzenlemelere yer vermiş ve bu kararın alınması bakımından usul ve esasları düzenlemiştir ${ }^{70}$.

66 Kurula seçilecek üyelerin niteliklerine ilişkin farklılıklar bağlamında detaylı bilgi için bkz. Düğmeci, s.249-250.

676701 sayılı Kanunun 10/I. maddesi.

686701 sayılı Kanunun 11/I-b. maddesi uyarınca; "Ayrımcılık yasağı ihlallerine iliş̧kin başvurular ile insan hakları veya ayrımcllk yasağı ihlallerine ilişkin resen yapılan incelemeleri karara bağlamak, bu bașvuru ve incelemelere ilişkin gerekli hâllerde uzlaşma sürecini sonuçlandırmak, ayrımcıllk yasă̆ı ihlallerine ilişsin bu Kanunda öngörülen idari yaptırımlara karar vermek".

696701 sayılı Kanunun 27. maddesi uyarınca; "Bu Kanunun uygulanmasına ilişkin yönetmelikler Kurum tarafindan yürürlüğe konulur".

706701 sayılı Kanunun 25. maddesi; Türkiye İnsan Hakları ve Eşitlik Kurumu Kanunun Uygulanmasına İlişkin Usul ve Esaslar Hakkında Yönetmeliğin 70. maddesi. 


\section{TÜRKIYE INSAN HAKLARI VE EŞITLIK KURULU'NUN AYRIMCILIK YASAĞI IHLALLERINI INCELEME USULÜ}

\section{A. KURUL'UN AYRIMCILIK YASAĞINI INCELEME KAPSAMINDA YETKISININ TEMELi}

Çağdaş anayasaların çoğu eşitliği bir hak olarak nitelendirmekte ve devletler de eşitliği gerçekleştirme yükümlülüğü taşımaktadır. Gerçekten de bir ülkede pozitif hukuk kuralları, doğal hukukun ilkelerine uydukları oranda değer kazanırlar. Herkesin hukuk karşısında eşit olması da doğal hukuk ilkelerinden biridir. Bu ilkenin gerçekleştirildiği hukuk sistemleri modern ve değerli sistemlerdir ${ }^{71} .1982$ Anayasası bağlamında açık bir şekilde kabul edilen eşitlik ilkesi, devletin temel yükümlülüklerinden biri olarak da düzenlenmiştir ${ }^{72}$. Anayasanın bu hükmünün, Avrupa İnsan Hakları Sözleşmesi 14. maddesinde olduğu gibi ayrımcılık yasağı șeklinde açıkça düzenlemeye sahip olmasa bile, ayrımcılık yasağını içerdiği düşünülmektedir ${ }^{73}$.

Uluslararası anlamdaki standartlar bakımından ayrımcllı; "Kamusal veya özel yaşamda, insan haklarım eşitlik temelinde tanınmasını, haklardan yararlanılmasını veya hakların kullanılmasın ortadan kaldırmak veya zayıflatmak amacını taşıyan veya böyle bir etki doğuran, herhangi bir ayrımcılık temeline dayanan, herhangi bir fark gözetme, dişlama, sınırlama veya kısıtlama ya da öncelik tanıma veya taciz ya da başkasına yönelik ayrımcılik yapılması talimatı veya örneğin engellilik veya din veya inanç temelinde herhangi bir kişinin ya da kuruluşun, bir hükmün, ölçütün veya uygulamanın beraberinde getirdiği dezavantajları kaldırmak için uygun tedbirlerin alınmaması" olarak tanımlanabilmektedir ${ }^{74}$.

Ayrımcıllğıı önlenmesi amacıyla "ayrımcılık yasaklı eşitlik" anlayışına da vurgu yapılması gereklidir. Bu bağlamda "Aynı durumda bulunan hak öznelerinin; hakl nedenler olmadikça, özellikle ırk, cinsiyet, dil, din ve inanç, siyasal ya da başka görüşler, yaş, engel, cinsel yönelim ve benzeri nedenlere dayah ayrım gözetilmeksizin aynı kurallara bağh olmasın ve yasaklama, kısıtlama, dışlama ya da yeğleme gibi eylemlere başvurmaksızın, tüm insan haklarından eşitlik koşulları içinde devlet ve işverenlerce yararlandırılmalarının sağlanmasını amaçlayan üstün bir ilke"nin sağlanması gereklidir ${ }^{75}$. İşte bu ilkeler kapsamında TïHEK’in ayrımcılık yasağını denetlerken hem uluslararası hukuk normlarını hem de ulusal mevzuatı gözden geçirmesi gerekecektir.

\footnotetext{
71 Abdullah Dinçkol, Hukuk Sosyolojisine Giriş, Der Yayınları, 2. Baskı, İstanbul 2021, s.52.

721982 Anayasası’nın "Kanun önünde eşitlik" başlıklı 10. maddesi uyarınca; "Herkes, dil, ırk, renk, cinsiyet, siyasî düşünce, felsefî inanç, din, mezhep ve benzeri sebeplerle ayırım gözetilmeksizin kanun önünde eşittir”. Aynı doğrultuda Türk Medeni Kanunu'nun 8. maddesi "Her insanın hak yeteneği vardır. Böylece bütün insanlar, kanun sınırları içinde, haklara ve borçlara yetenekli olmada eşittir." demekle bütün insanları "hak yeteneği” açısından ayırım yapmaksızın eşit saymaktadır. Dinçkol, s.52.

73 Ulaş Karan, “Eşitlik İlkesi ve Ayrımcılık Yasağı”, İnsan Hakları Avrupa Sözleşmesi ve Anayasa, 3. Baskı, Beta Yayınevi, İstanbul, s.460.

74 Karan, s.461.

75 Mesut Gülmez, İnsan Hakları ve Avrupa Birliği Hukukunda Ayrımcılığın Kaldırılması ve Türkiye, AB’ye Sosyal Uyum Dizisi, Ankara, 2009, s.43.
} 


\section{670 I Sayılı Kanun Kapsamında Eşitlik IIkesi ve Ayrımcılık Yasağının Kapsamı}

6701 sayılı Kanun ayrımcılık yasağı kapsamında Anayasa’nın 10. maddesi doğrultusunda bir düzenlemeye yer vermektedir. 6701 sayılı Kanun'un "Eşitlik ilkesi ve ayrımcılık yasağı” başlıklı 3. maddesi uyarınca;

“(1) Herkes, hukuken tanınmış hak ve hürriyetlerden yararlanmada eşittir.

(2) Bu Kanun kapsamında cinsiyet, ırk, renk, dil, din, inanç, mezhep, felsefi ve siyasi görüş, etnik köken, servet, doğum, medeni hâl, sağlık durumu, engellilik ve yaş temellerine dayalı ayrımcılık yasaktır".

Ayrımcılık eylemi konularının kanunda sayılmasının yanı sıra kanun koyucu, 6701 sayılı Kanun'da ayrımcılık yasağı alanlarının kapsamını da düzenlemiştir ${ }^{76}$. "Ayrımcılık yasağının kapsamı" başlıklı 5. madde uyarinca;

“(1) Eğitim ve öğretim, yargı, kolluk, sağlık, ulaşım, iletişim, sosyal güvenlik, sosyal hizmetler, sosyal yardım, spor, konaklama, kültür, turizm ve benzeri hizmetleri sunan kamu kurum ve kuruluşları, kamu kurumu niteliğindeki meslek kuruluşları, gerçek kişiler ve özel hukuk tüzel kişileri, yürüttükleri faaliyetler bakımından bu hizmetlerden yararlanmakta olan veya yararlanmak üzere başvurmuş olan ya da bu hizmetler hakkında bilgi almak isteyen kişi aleyhine ayrımcılık yapamaz. Bu hüküm kamuya açık hizmetlerin sunulduğu alanlar ve binalara erişimi de kapsar.

(2) Birinci fikrada belirtilen hizmetlerin planlanması, sunulması ve denetlenmesinden sorumlu olan kişi ve kurumlar, farklı engelli grupların ihtiyaçlarını dikkate almakla ve makul düzenlemelerin yapılmasını sağlamakla yükümlüdür.

(3) Kamu kurum ve kuruluşları, kamu kurumu niteliğindeki meslek kuruluşları, gerçek kişiler, özel hukuk tüzel kişileri ve bunlar tarafindan yetkilendirilenler, taşınır ve taşınmazları kamuya açı bir şekilde sunarken bu malları edinmek veya kiralamak isteyenler ile bunlar hakkında bilgi almak isteyenler aleyhine, bunların kiralanması, kira akdinin şartlarının belirlenmesi, kira akdinin yenilenmesi veya sona erdirilmesi, satışı ve devri süreçlerinin hiçbirinde ayrımcılık yapamaz.

(4) Dernek, vakıf, sendika, siyasi parti ve meslek örgütlerine, ilgili mevzuatlarında veya tüzüklerinde belirtilen istisnalar dişında üye olma, organlarına seçilme, üyelik imkânlarından yararlanma, üyeliğin sonlandırılması ve bunların faaliyetlerine katılma ve yararlanma baklmından, hiç kimse aleyhine ayrımcılık yapılamaz."

Hükümden de anlaşılacağı üzere sadece kamu kurumlarının değil, kanunda belirtilen alanlarda faaliyette bulunan gerçek ve özel hukuk tüzel kişilerinin de ayrımcılık yasağını ihlal etmeleri durumunda haklarında incelemenin başlatılacağı açıktır. 
6701 sayılı Kanun hizmet alanları dışında ayrıca "İstihdam ve serbest meslek” başlıklı 6. madde ile işçi istihdam edenler ve serbest meslek çalışanlarına da ayrımcılık yasağı yükümlülüğü getirmiştir. Hüküm uyarınca;

“(1) İsveren veya işveren tarafından yetkilendirilmiş kişi; işverenin çalışanı veya bu amaçla başvuran kişi, uygulamal iş deneyimi edinmek üzere bir işyerinde bulunan veya bu amaçla başvuran kişi ve herhangi bir sıfatla çalışmak ya da uygulamalı iş deneyimi edinmek üzere işyeri veya iş ile ilgili olarak bilgi edinmek isteyen kişi aleyhine, bilgilenme, başvuru, seçim kriterleri, işe alım şartları ile çalışma ve çalışmanın sona ermesi süreçleri dâhil olmak üzere, işle ilgili süreçlerin hiçbirinde ayrımcılık yapamaz.

(2) Birinci fikra iş ilanı, işyeri, çalışma şartları, mesleki rehberlik, mesleki eğitim ve yeniden eğitimin tüm düzeylerine ve türlerine erişim, meslekte yükselme ve mesleki hiyerarşinin tüm düzeylerine erişim, hizmet içi eğitim, sosyal menfaatler ve benzeri hususları da kapsar.

(3) İsveren veya işveren tarafindan yetkilendirilmiş kişi, istihdam başvurusunu gebelik, annelik ve çocuk bakımı gerekçeleriyle reddedemez.

(4) Serbest mesleğe kabul, ruhsat, kayıt, disiplin ve benzeri hususlar bakımından ayrımcılık yapilamaz.

(5) 22/5/2003 tarihli ve 4857 sayıl İş Kanunu kapsamına girmeyen her türlü iş ve iş görme sözleşmeleri de bu madde kapsamındadır.

(6) Kamu kurum ve kuruluşlarında istihdam bu madde hükümlerine tabidir.”

Bu doğrultuda Anayasa’nın 49. maddesi kapsamında yer alan çalışma hakkının korunması anlamında, 6701 sayılı Kanun'un ayrımcılık yasağının kapsamını geniş tuttuğu görülmektedir.

Ayrımcılık niteliğinde davranışları ise kanun koyucu 6701 sayılı Kanun'un 4. maddesi ile sıralamıştır. Bu kapsamda; ayrı tutma, ayrımcılık talimatı verme ve bu talimatları uygulama, çoklu ayrımcılık, doğrudan ayrımcılık, dolaylı ayrımcılık, işyerinde yıldırma, makul düzenleme yapmama, taciz, varsayılan temele dayalı ayrımcılık türleri Kanun'da tanımlanmış bulunmaktadır. 6701 sayılı Kanun'un 4/II. maddesi kapsamında ayrımcılık davranışlarına tabi tutulan kişinin hakkının aranması bağlamında idari ve adli yollara başvurması nedeniyle başvurucu ya da vekili hakkında ayrıca ayrımcılık davranışlarında bulunulması ise yine ayrımcılık bakımından incelenmesi gereken yeni bir husus olarak ortaya çıkmaktadır ${ }^{77}$. Kanunda sayılan bu davranışlar haricinde çeşitli farklı ayrımcılık tutum ve davranışlarının da yine Kurul tarafından incelenmesi gerekecektir ${ }^{78}$.

77 Doktrinde bu durum mağdurlaştırma olarak belirtilmektedir. Detaylı inceleme için bkz. Karan, s282.

78 Dolayısıyla ayrımcılık ve ayrı tutma gibi davranışların da ayrıca TİHEK’in inceleme altına alma yetkisinin olduğu belirtilmektedir. Düğmeci, s.312 - 317 . 


\section{670 I Sayılı Kanun Kapsamında Ayrımcılık Yasağına İstisna Oluşturan Ayrımcılık Iddiasının ileri Sürülemeyeceği Haller}

Aynı hukuki statü içinde bulunan herkese eşit davranılması gerekliliği anayasal bağlamda korunan bir hak olarak karşımıza çıkmaktadır. Ancak kimi zaman aynı tutum ve davranışları göstermemek, kişiler arasında farklılığı ortaya çıkarmak ayrımcılık olmamaktadır. Diğer bir deyişle her farklı tutum ve davranış ayrımcılığı oluşturmaz ${ }^{79}$. Bu tip davranışların hukuki düzenlemelerle farklılığının ortaya konmasında, ayrımcılığın ortaya çıkmayacağı belirtilmektedir ${ }^{80}$. İşte bu kapsamda hukuki düzenlemelerden birisi de 6701 sayılı Kanun’un 7. maddesinde belirtilmiştir. Hüküm uyarınca istisnalar şu şekilde sıralanmıştır;

“a) İstihdam ve serbest meslek alanlarında, zorunlu mesleki gerekliliklerin varlığı hâlinde amaca uygun ve orantil olan farklı muamele.

b) Sadece belli bir cinsiyetin istihdamın zorunlu kılan durumlar.

c) İse kabul ve istihdam sürecinde, hizmetin zorunlulukları nedeniyle yaş sınırlarının belirlenmesi ve uygulanması, gereklilik ve amaçla orantılı olması şartıyla yaşa dayalı farklı muamele.

c) Çocuk veya özel bir yerde tutulması gereken kişilere yönelik özel tedbirler ve koruma önlemleri.

d) Bir dine ait kurumda, din hizmeti veya o dine ilişkin eğitim ve öğretim vermek üzere sadece o dine mensup kişilerin istihdamı.

e) Dernek, vakıf, sendika, siyasi parti ve meslek örgütlerinin, ilgili mevzuatlarında veya tüzüklerinde yer alan amaç, ilke ve değerler temelinde üye olacak kişilerde belli şart ve nitelik aramalart.

f) Eşitsizlikleri ortadan kaldırmaya yönelik, gerekli, amaca uygun ve orantılı farklı muamele.

g) Vatandaş olmayanların ülkeye giriş ve ikametlerine ilişkin şartlarından ve hukuki statülerinden kaynaklanan farklı muamele."

İstisnaların numerus clausus ilkesi ile sınırlı tutulması, ayrımcılık yasağının genişletilmesini önleme ve hukuki güvenin sağlanması açısından gereklidir. Bu sayede genel kaide olarak ayrımcılık yasağı korunmuş olacaktır.

79 Düğmeci, s.339.

80 Karan, s.284. 


\section{B. AYRIMCILIK YASAĞININ IHLAL EDILDIĞINE DAIR IDDIANIN INCELENMESi}

Ayrımcılık yasağının ihlal edilip edilmediği yönünde bir kararı alabilmek için TİHEK’in öncelikle bu kapsamda duyum almış olması gerekir. Sonrasında ise Kurulun karşısına gelen iddiaları inceleyerek, somut olayın değerlendirilmesi bakımından 6701 sayılı Kanun ile Türkiye İnsan Hakları ve Eşitlik Kurumu Kanunun Uygulanmasına İlişkin Usul ve Esaslar Hakkında Yönetmeliğinde yer alan araştırma araçlarını kullanarak hem maddi gerçeğe ulaşmaya çalışması hem de bunun sonucunda ilgili kararı vermesi gerekecektir.

\section{Ayrımcılık Yasağının Ihlal Edildiğine Dair Iddianın Kurul’a Ulaşması}

TİHEK'in ayrımcılık yasağının ihlal edildiğine dair incelemelere başlayabilmesi için Kurum’a bu yönde bir bilginin gelmesi gerekmektedir. Bu bilginin gelmesiyle Kurul'un inceleme yetkisi doğacaktır.

Ayrımcılık yasağının ihlal edilmesi hususu kimi zaman bir idari faaliyet kapsamında bir idari işlemin tesisi ile de meydana gelebilmektedir. Bu doğrultuda ayrımcılık yasağının ihlal edildiğine yönelik ilgili idari işlemlere karşı açılacak dava açma süresi içinde TİHEK’e yapılmış olan başvurular, işlemeye başlamış olan dava açma süresini durdurmaktadır ${ }^{81}$. Diğer bir deyişle Kurum'a ulaşan ayrımcılık yasağı ihlali konulu idari işlemler bakımından karar verilinceye kadar, idari işleme karşı açılacak iptal davasının süresi durmaktadır. 6701 sayılı Kanun'un 17 / III. maddesi, bu sürelerin duracağını hüküm altına almıştır.

6701 sayılı Kanun, Kurul'un iki farklı yöntemle ayrımcılık yasağını ihlal iddialarından haberdar olması durumunu belirtmiştir. Kanunun 17. maddesinde belirtilen bu durumlardan birisi Kurum’a başvuru ile harekete geçilmesi, diğeri ise Kurum'un aldığı duyum üzerine resen harekete geçmesidir.

\section{a. Kendisine Yapılan Başvuru Üzerine Kurulun Harekete Geçmesi}

Başvurular bakımından ayrımcılık yasağı ihlalinden zarar gördüğünü iddia eden her gerçek ve tüzel kişinin hakkı bulunmaktadır ${ }^{82}$. 6701 sayılı Kanun’un "Başvurular” başlıklı 17. maddesi bu hakkın tanımlamasını yapmaktadır. Fakat Türkiye İnsan Hakları ve Eşitlik Kurumu Kanununun Uygulanmasına İlişkin Usul ve Esaslar Hakkında Yönetmelik kapsamında başvurucular bakımından daha sınırlayıcı bir hükmün yer aldığını belirtmemiz gerekir ${ }^{83}$. Yönetmeliğin 30. maddesinde sadece, "Eğitim ve öğretim, yargı, kolluk, sağlık, ulaşım, iletişim, sosyal güvenlik, sosyal hizmetler, sosyal yardım, spor, konaklama, kültür, turizm ve benzeri hizmetleri sunan kamu kurum ve kuruluşları, kamu kurumu niteliğindeki meslek kuruluşları, gerçek kişiler ve özel hukuk tüzel kişilerinin, yürüttükleri faaliyetler bakımından bu hizmetlerden yararlanmakta olan veya yararlanmak üzere başvurmuş olan

81 Gürsel Kaplan, İdari Yargılama Hukuku, 3. Baskı, Ekin Basın Yayın Dağıtım, Bursa, Ocak 2018, s.29.

82 Kalabalık, s.352.

83 Düğmeci, s.353. 
ya da bu hizmetler hakkında bilgi almak isteyen her gerçek veya tüzel kişi”lerin başvuru hakkına sahip olduğu belirtilmektedir.

Kurulun başvuruyu incelemesinden önce, başvuru sahibinin ihlali işleyene, ihlalin düzeltilmesi yönünde başvurması gerekir. 6701 sayılı Kanun'un 17 / II. maddesi uyarınca ilgililer TİHEK’e başvurmadan önce, bu kanuna aykırı olduğunu iddia ettikleri davranışın düzeltilmesi için bu davranışta bulunan taraftan talep etmek zorundadırlar. Hem Kanun'un 17 / II. maddesi hem de Yönetmeliğin "Kanuna aykırı olduğu iddia edilen uygulamanın düzeltilmesinin ilgili taraftan talep edilmesi" başlıklı 39. maddesi kapsamında, iddiaya muhatap olan taraf talebi red eder ya da talebin kendisine yapılmasından itibaren 30 gün içinde cevap vermezse, iddiada bulunan ilgili TİHEK'e başvurusunu yapabilme hakkını kazanacaktır. Kurul kararlarında da bu hususun özellikle vurgulandığg görülmektedir. Kurul tarafından verilmiş olan bir kararda "Mezkur Kanun'un 17'nci maddesinin ikinci fikrasında yer alan ... hükmü uyarınca başvuran, Kuruma başvurmadan önce uygulamanın düzeltilmesini ilgili taraftan talep etmelidir" hususu özellikle vurgulanmıştır ${ }^{84}$.

TİHEK’e başvurmadan önce ayrımcllık yasağını ihlal ettiğine dair faaliyette bulunanlara ilgililer tarafından başvurmanın istisnası da 6701 sayılı Kanun'un 17 / II. maddesinde yer almaktadır ${ }^{85}$. Eğer ayrımclık yasağını ihlal edenlere başvuru ile telafisi güç veya imkânsız zararların ortaya çıkması ihtimali bulunuyorsa, ilgililer doğrudan TïHEK’e başvurabileceklerdir.

\section{b. Duyum Alması Üzerine Kurulun Resen Harekete Geçmesi}

TİHEK, ayrımcılık yasağının ihlal edildiğine dair duyum almasıyla resen harekete geçme yetkisine sahiptir. Sosyal medya, medya organları gibi kitle iletişim araçları ile ya da başka vasıtalarla haberdar olunduğu takdirde, TïHEK denetim sürecini başlatabilmektedir ${ }^{86}$.

Kurumun duyum üzerine harekete geçebilmesindeki temel amacın, ayrımcı eylemden veya işlemden dolayı kişilerin mağdur olmasıyla, bu kişilerin haklarının sağlanabilmesi fikri olduğu düşünülebilmektedir ${ }^{87}$. Korku, bilgisizlik ve benzeri nedenlerle baskılanan mağdurlara bu kapsamda yardım sağlanmış olacaktır.

6701 sayılı Kanun'un 17 / VI. maddesi uyarınca;

"İnsan hakları ve ayrımcıllk yasağı ihlallerine ilişkin resen yapılan incelemeler için ihlal mağdurunun ş̧ahsen belirlenebilir olduğu durumlarda kendisinin veya kanuni temsilcisinin açık rızasının alınması şarttır. Ancak, çocuğun yüksek yararının gerektirdiği hâllerde kanuni temsilcisinin rizası aranmaz".

84 Türkiye İnsan Hakları ve Eşitlik Kurulu’nun 2020/182 sayılı ve 25.08.2020 tarihli kararı.

85 Kalabalık, s.352.

86 Düğmeci, s.353.

87 Karan, s.516. 
Bu doğrultuda korunması amaçlanan mağdurun çocuk olması durumunda, çocuğun korunması adına kanun koyucu lehe bir istisna geliştirmiştir ${ }^{88}$. Çocuğun yüksek yararı karşısında kanuni temsilcinin rızasının geri planda bırakılması da yine hükmün geneli bakımından farklılık yaratmayacaktır.

6701 sayılı Kanun ile Türkiye İnsan Hakları ve Eşitlik Kurumu Kanunun Uygulanmasına İlişkin Usul ve Esaslar Hakkında Yönetmelik kapsamında da açık bir şekilde, TİHEK’in ayrımcılık yasağı ihlallerinde resen hareket edebileceği belirtilmiştir ${ }^{89}$. Yetkinin kullanılmasına ilişkin Yönetmeliğin “Başvuru üzerine veya resen inceleme usulü” başlıkl1 51. maddesinde de resen başlatılacak inceleme ile ihlal iddiasına muhatap olan taraftan yazılı görüşün istenebileceği hüküm altına alınmıştır. Ayrıca "İncelenme ve araştırmanın sonlandırılamayacağı haller" başlıklı 63. madde kapsamında hangi hallerde başvurucunun iradesine bağlı kalınmaksızın incelemeye resen devam edileceği sayılmıştır ${ }^{90}$.

\section{Ayrımcılık Yasağının ihlal Edildiğine Dair Iddianın Kurul Tarafından Incelenmesi}

Ayrımcılık ihlalleri iddialarının TİHEK’e gelmesiyle beraber, 6701 sayılı Kanun'un 18 ve 19. maddeleri kapsamında inceleme süreci başlamaktadır ${ }^{91}$. Türkiye İnsan Hakları ve Eşitlik Kurumu Kanununun Uygulanmasına İlişkin Usul ve Esaslar Hakkında Yönetmelik'in 6. Bölümü olan "Ön İnceleme Bölümü” kapsamında incelenemezlik kararı ya da kabul edilmezlik kararı verilmediği takdirde, Kurul ayrımcılık yasağının ihlal edildiğine dair iddianın incelenmesine başlamaktadır ${ }^{92}$. TİHEK özellikle, kendi görev alanına girmeyen başvurular ile hakkın kötüye kullanılması niteliğindeki başvuruları red ederek, herhangi bir işleme tabi tutmamaktadır ${ }^{93}$. Bu kapsamdaki başvurular için incelenemezlik karar1 verilmektedir ${ }^{94}$.

Başvurunun 6701 sayılı Kanun ile Yönetmeliğe uygun bir şekilde tamamlanmış ve ön inceleme aşamasından geçmiş olması sonucunda, Kurul tarafından inceleme aşamasına geçilmektedir. Bu safhada Kurul, Yönetmeliğin 50. maddesi uyarınca;

88 Düğmeci, s.353.

896701 sayılı Kanun ile Türkiye İnsan Hakları ve Eşitlik Kurumu Kanununun Uygulanmasına İlişkin Usul ve Esaslar Hakkında Yönetmelik'in "Kurumun çalışma alanları" başlıklı 24/I-g. maddesi uyarınca; “Ayrımcılık yasağı ihlallerini resen veya başvuru üzerine incelemek, araştırmak, karara bağlamak ve sonuçlarını takip etmek” yetkisi Kurum’a tanınmıştır.

906701 sayılı Kanun ile Türkiye İnsan Hakları ve Eşitlik Kurumu Kanununun Uygulanmasına İlişkin Usul ve Esaslar Hakkında Yönetmelik'in 63.maddesi uyarınca; "Başvurudan vazgeçme, başvurunun uzlaşma ile sonuçlanması ve başvurucunun veya ilgili gerçek kişi tarafin ölümü veya tüzel kişiliğinin sona ermesi hâllerinde başvuru konusunun; insan haklarına, temel hak ve özgürlüklere, engelli haklarına, kadın haklarına, çocuk haklarına ve kamuyu ilgilendiren genel konulara yönelik olması durumunda resen inceleme ve araştırmaya devam edilebilir".

916701 sayılı Kanun ile Türkiye İnsan Hakları ve Eşitlik Kurumu Kanununun "İhlal incelemeleri” başlıklı 18. maddesi ve "İnceleme yetkisi" başlıklı 19. maddesi.

92 Türkiye İnsan Hakları ve Eşitlik Kurumu Kanununun Uygulanmasına İlişkin Usul ve Esaslar Hakkında Yönetmelik’in 47, 48 ve 49 . maddeleri.

93 Düğmeci, s.357.

94 Türkiye İnsan Hakları ve Eşitlik Kurumu Kanununun Uygulanmasına İlişkin Usul ve Esaslar Hakkında Yönetmelik’in "İncelenemezlik kararı" başlıklı 66. maddesi. 
“Eğitim ve öğretim, yargl, kolluk, sağllk, ulaşım, iletişim, sosyal güvenlik, sosyal hizmetler, sosyal yardım, spor, konaklama, kültür, turizm ve benzeri hizmetleri sunan kamu kurum ve kuruluşları, kamu kurumu niteliğindeki meslek kuruluşları, gerçek kişiler ve özel hukuk tüzel kişilerinin yürüttükleri faaliyetler, insan onurunu temel alarak insan haklarının korunması ve geliştirilmesi, kişilerin eşit muamele görme hakkının güvence altına alınması, hukuken tanınmış hak ve hürriyetlerden yararlanmada cinsiyet, ırk, renk, dil, din, inanç, mezhep, felsefi ve siyasi görüş, etnik köken, servet, doğum, medeni hâl, sağlık durumu, engellilik ve yaş temellerine dayalı ayrımcılı̆̆ın önlenmesi yönlerinden" inceleme yapar ${ }^{95}$.

İnceleme yetkisi kapsamında Kurul, 6701 sayılı Kanun kapsamında TİHEK’e tanınmış olan tüm yetkileri kullanma hakkına sahiptir. Özellikle Yönetmeliğin "İnceleme yetkisi” başlıklı 55. maddesi kapsamında Kurul, inceleme, araştırma, ziyaret ve rapor hazırlama görevlerini TİHEK’in personelini kullanarak yerine getirir. Ayrıca ilgili taraftan bilgi ve belge isteme ${ }^{96}$, ilgili kurum ve kuruluşlarınca heyet oluşturma ${ }^{97}$, bilirkişi görevlendirme ${ }^{98}$ ve tanık dinleme ${ }^{99}$ gibi birçok yetkiyi de Kurul, somut olayı çözümleyebilme açısından kullanabilmektedir.

\section{TÜRKIYE INSAN HAKLARI VE EŞiTLIK KURULU'NUN TESPIT ETTIĞi AYRIMCILIK YASAĞI IHLALLERINE ILIŞKIN IDARI YAPTIRIM YETKISI}

\section{A. KURUL'UN IDARI YAPTIRIM YETKISINI KULLANMASI}

İdare, kamu düzeninin sağlanması adına faaliyet konusuna ilişkin alandaki mevzuat çerçevesinde her türlü yaptırımı uygulayabilmektedir ${ }^{100}$. Bu anlamda her yaptırımın çıkış noktasının, hukuk düzenini bozan davranışları cezalandırma iradesinden kaynaklandığı açıktır ${ }^{101}$.

Yaptırım uygulama yetkisi, denetleme yetkisinin kullanılmasının bir sonucudur. Özellikle idari kolluk faaliyetleri bakımından önem arz eden idari yaptırım yetkisinin kullanılması, idarenin kamu düzenini korunması için en etkili silahlarından birisidir. Duran’a göre idari kolluk, kamu düzeninin sağlanması, korunması ve bozulduğunda geri getirilmesi amaciyla bireylerin toplum içindeki tutum ve davranışlarının düzenlenmesi, gözetilip izlenmesi ve aykırı eylem ve durumların

95 Türkiye İnsan Hakları ve Eşitlik Kurumu Kanununun Uygulanmasına İlişkin Usul ve Esaslar Hakkında Yönetmelik’in "İncelemede uyulacak ilkeler" başılıkı 50. maddesi.

96 Türkiye İnsan Hakları ve Eşitlik Kurumu Kanununun Uygulanmasına İlișkin Usul ve Esaslar Hakkında Yönetmelik'in "İlgili taraftan bilgi ve belge istenmesi" başlıklı 56. maddesi.

97 Türkiye İnsan Hakları ve Eşitlik Kurumu Kanununun Uygulanmasına İlişkin Usul ve Esaslar Hakkında Yönetmelik'in "Heyet oluşturma" başlıklı 57. maddesi.

98 Türkiye İnsan Hakları ve Eşitlik Kurumu Kanununun Uygulanmasına İlişkin Usul ve Esaslar Hakkında Yönetmelik’in "Bilirkişi görevlendirilmesi" başlıklı 58. maddesi.

99 Türkiye İnsan Hakları ve Eşitlik Kurumu Kanununun Uygulanmasına İlişkin Usul ve Esaslar Hakkında Yönetmelik'in "Tanık dinlemesi" başlıklı 59. maddesi.

100 Akyılmaz / Sezginer / Kaya, s.598.

101 Tan, s.408. 
gerektiğinde kuvvet de kullanarak önlenmesi, engellenmesi ve kaldırılmasıdır ${ }^{102}$. Dolayısıyla kamu düzenini bozucu nitelikteki eylemlere, kamu düzeninin tekrar sağlanması amacıyla idari yaptırım uygulanması kaçınılmazdır.

TİHEK, insan hakları ihlalleri kapsamında yaptığı incelemelerden sadece ayrımcılık yasağının ihlal edilmesi kapsamında bağlayıcı bir karar uygulayabilmektedir. TİHEK’e, ayrımcılık yasağını ihlal edenlere karşı mücadele edebilmesi anlamında 6701 sayılı Kanun, "idari yaptırım” silahını sunmuştur. 6701 sayılı Kanun'un "İdari yaptırımlar” başlıklı 25. maddesi; “Ayrımcılık yasă̆ının ihlali hâlinde, bu ihlalin etki ve sonuçlarının ă̆ırlı̆̆ı, failin ekonomik durumu ve çoklu ayrımcılı̆̆ın ağırlaştırıcı etkisi dikkate alınarak ihlalden sorumlu olan kamu kurum ve kuruluşları, kamu kurumu niteliğindeki meslek kuruluşları, gerçek kişiler ve özel hukuk tüzel kişileri hakkında” idari para cezası uygulanacağını belirtmiştir ${ }^{103}$.

Ayrımcılık yasağının ihlali kapsamında idari yaptırıma tabi tutulması gereken fiil kimi zaman bir suça konu olabilirken, kimi zaman ise başka bir kanunda yer alan idari yaptırıma karşılık gelen bir fiili oluşturabilmektedir. Ayrımcılık yasağı ihlalinin ayrıca suç teşkil etmesi ve adli yargıda suça ilişkin yargılamanın görülmesi, Kurulun idari yaptırım kararı vermesine engel değildir ${ }^{104}$. Yönetmeliğin 54 / II. maddesi kapsamında bir ayrımcılık yasağının ihlali niteliğindeki fiilin sadece suç niteliğinde olması değil, ayrıca başka kanunlardaki idari yaptırımların uygulanmasını gerektirecek nitelikte olması da 6701 sayılı Kanun kapsamında uygulanacak idari para cezasını engellemez ${ }^{105}$. Konuya ilişkin olarak Kurul vermiş olduğu bir kararda, bir fiil her ne kadar ceza yargılamasına tabi tutulsa da olayda ayrıca idari yaptırımın uygulanmasına bir engel bulunmadığ belirtilmiştir $^{106}$. Kurul'un vermiş olduğu bu kararın karşı oy yazısında, yargıya intikal etmiş bir konunun artık görev alanından çıktığı ifade edilmiştir. Ancak bu yorumun, Yönetmeliğin 54 / II. maddesine uygun olmayacağını düşünmekteyim.

\section{Kurul'un Idari Para Cezasını Uygulaması}

TİHEK'in, 6701 sayılı Kanun'un 25. maddesi kapsamında, ayrımcılık yasağının ihlaline ilişkin uygulayacağı idari para cezasının sınırı onbeş bin Türk Lirasıdır. Bu yaptırım bir cezai uygulama olması neticesiyle, ayrımcılık fiilinden mağdur olan gerçek ya da tüzel kişiler lehine bir kazanç ya da tazminat faydası sağlamamaktadır. Mağdurlar bu doğrultuda ayrıca hukuk mahkemelerinde zararlarının tazminini talep edebileceklerdir ${ }^{107}$.

102 Lütfi Duran, İdare Hukuku Ders Notları, İstanbul, 1982, s.505.

103 Aynı doğrultuda Türkiye İnsan Hakları ve Eşitlik Kurumu Kanunun Uygulanmasına İlişkin Usul ve Esaslar Hakkında Yönetmeliğinin "İdari yaptırım" başılılı 70. maddesi, idari yaptırım kararının uygulanması sürecini düzenlemektedir.

104 Kalabalık, s.355.

105 Türkiye İnsan Hakları ve Eşitlik Kurumu Kanununun Uygulanmasına İlişkin Usul ve Esaslar Hakkında Yönetmelik'in "Kurulun suç duyurusunda bulunacağı haller" başlikl 54/II. maddesi uyarınca; "Konusu suç teşkil eden insan hakları veya ayrımcıllk yasağı ihlalleriyle ilgili suç duyurusunda bulunulması veya bu fillerin diğer kanunlar uyarınca idari yaptırıma bağlanmış olması, aynı fiile Kanun kapsamında idari yaptırım kararı verilmesine engel teşkil etmez".

106 Kurul'un 01.12.2020 tarih ve 2020/244 sayılı kararı.

107 Düğmeci, s.367. 
TİHEK, mağdurların ayrımcılık ihlali ile karşılaşmaları kapsamında ihlali gerçekleştiren faaliyetlerde bulunanlar bakımından yaptırım uygulayabileceği gibi, başvuru mağdur ile ihlalci arasında bir uzlaşı sağlayabilme yetkisine de sahiptir. 6701 sayılı Kanunun 18 / III. maddesi kapsamında TİHEK Başkanı, tarafları uzlaşmaya davet ederek, ihlalin sona erdirilmesini ve belli bir tazminat ödenmesi için uyuşmazlığın çözümlenmesi amacıyla çalışma yapabilmektedir ${ }^{108}$.

6701 sayılı Kanun ile Yönetmelik kapsamında Kurul’a, ayrımcılık yasağını ihlal edenlere karşı uygulanacak idari yaptırımın alt ve üst sınırını belirleme takdir yetkisi sunulmuştur. Bu doğrultuda Kurul karar alırken, failin ekonomik durumunu, çoklu ayrımcılığın mevcut olup olmamasını ve ihlalin etki ve sonuçlarının ağırlığını dikkate almaktadır ${ }^{109}$.

İhlalin tespitiyle miktarın kesinleştirilmesi bakımından da belirleyici çeşitli hükümlere ihtiyaç duyulmaktadır. Hukuka aykırı davranışın yaptırım ile karşılık bulmasında idari yaptırım ile ayrımcılık yasağının ihlali niteliğindeki davranış arasında ölçülülügün korunması gerekmektedir. Dolayısıyla idari yaptırım sınırının daha da keskin çizgilerle belirlenmesi gerekecektir. Alt ve üst sınırın somut olaylarda nasıl uygulanacağı sorunu, diğer düzenleyici ve denetleyici kurumların işleyişinin örnek olarak kullanılmasıyla da çözümlenebilir. Örneğin Rekabet Kurumu’nun idari para cezasını uygulaması yönünden tatbik ettiği Rekabeti Sınırlayıcı Anlaşma, Uyumlu Eylem ve Kararlar ile Hâkim Durumun Kötüye Kullanılması Halinde Verilecek Para Cezalarına İlişkin Yönetmelik, Rekabet Kurumu’nun faaliyetlerinin düzenlenmesi bakımından öngörülebilir bir öneme sahiptir ${ }^{110}$. TİHEK'in de özellikle ayrımcılık yasağının ihlali kapsamında uygulayacağı idari yaptırımları, benzeri bir düzenleyici işleme dayalı olarak tesis etmesi, hukuk devleti ilkesi bakımından da öngörülebilirliği sağlayacaktır.

6701 sayılı Kanun, idari yaptırımı gerektirecek fiillerin tekerrürü halini de düzenlemiş bulunmaktadır. Fakat bu tekerrür hali sadece ilk olarak verilen cezanın, idari para cezası yerine uyarı cezası olarak uygulanmasında geçerli olabilecektir. 6701 sayılı Kanunun 25 / IV. maddesi uyarınca; "Kurul, verdiği idari para cezasın bir defaya mahsus olmak üzere uyarı cezasına dönüştürebilir. Hakkında uyarı cezası verilen kişi veya kurumun ayrımcı filinin tekrarı hâlinde alacağı ceza yüzde elli oranında artırılır. Bu artışceza üst sınırını aşamaz". Bu doğrultuda ilk fiil kapsamında hakkında idari para cezası yaptırımı uygulanan ilgilinin ikinci ihlal fiili için tekerrür hükmü yerine doğrudan idari para cezasının uygulanacağı açıktır.

1086701 sayılı Kanun ile Türkiye İnsan Hakları ve Eşitlik Kurumu Kanununun "İhlal incelemeleri” başlıklı 18. maddesi ve "İhlal incelemeleri" başlıklı 18/III. ve 18/IV. maddesi uyarınca; "Başkan, incelemenin özelliğine göre, görüşlerin alınmasından sonra, resen veya talep üzerine tarafları uzlaşmaya davet edebilir. Uzlaşma, insan hakları veya ayrımcilı yasağı ihlali olduğu iddia olunan uygulamaya son verilmesi veya mağdur açısından bu sonucu sağlayacak çözümleri içerebileceği gibi mağdura belli bir tazminatın ödenmesi biçiminde de olabilir. Uzlaşma en geç bir ay içinde sonuçlandırılır. Uzlaşma müzakereleri sırasında yapılan tespitler, alınan beyanlar veya açıllamalar, herhangi bir soruşturma ve kovuşturmada ya da davada delil olarak kullanılamaz.

Uzlaşma yoluyla sonuçlandırılamayan başvurular ve incelemeler hakkında ilgili rapora ilişkin müzekkere yirmi gün içinde Kurula sunulur. Bunun üzerine Kurul, insan hakları veya ayrımcılı yasağı ihlali yapıllp yapılmadı̆̆ına ilişkin karar verir."

109 Eren, Türkiye İnsan Hakları ve Eşitlik Kurumu, s.131.

11027142 sayı ve 15.02.2009 tarihli Resmi Gazete'de yayımlanan Rekabeti Sınırlayıcı Anlaşma, Uyumlu Eylem ve Kararlar ile Hâkim Durumun Kötüye Kullanılması Halinde Verilecek Para Cezalarına İlişkin Yönetmelik. 


\section{Kurul'un Uyarı Cezasının Uygulaması}

TİHEK'in yaptırım uygulamaları kapsamında idari para cezasının dişında, uyarı cezası da bulunmaktadır. 6701 sayılı Kanunun 25/IV. maddesi kapsamında Kurul, bir defaya mahsus olmak üzere idari para cezasını uyarı cezasına çevirebilmektedir. Buradaki temel amaç, faalin sslah edilmesidir ${ }^{111}$. TİHEK bu yetki kullanırken, ihlali yapanın bu ihlali sona erdireceği ve bir daha yapmayacağına dair inancının bulunması gerekir ${ }^{112}$.

Kurul'un uyarı cezasına ilişkin yetkisini kullandığı somut kararların da alındığı görülmektedir ${ }^{113}$. Ayrımcılık yasağının ihlal edildiği saptanan bir kararda, idari para cezası uyarı cezasına dönüştürülmüş ancak takdir yetkisinde bulunan bu husus karara bağlanırken gerekçe yönünden bir yorumda bulunulmamıştır. Her ne kadar 6701 sayılı Kanun’un 25. maddesi ve Yönetmeliğin 70. maddesi kapsamında idari para cezasının uyarı cezasına dönüştürülmesinin gerekçesinin belirtilmesi yönünde açıllık bulunmasa da verilecek kararlarda bu yönde gerekçelendirmede bulunmak, idare hukukunun temel özellikleri bakımından lüzumludur. İdari işlem niteliğine sahip olan idari yaptırımın sebep ve konu unsurlarının belirlenebilmesi açısından da öneme sahip olan gerekçeli olma ilkesi, şekil unsurunun en önemli kriterlerinden birisidir ${ }^{114}$. Bu nedenle idari para cezasının uyarı cezasına dönüştürülmesi yönünde verilecek kararında ana karar içinde gerekçelendirilmesi yerinde olacaktır.

\section{B. KURUL'UN IDARI YAPTIRIM UYGULANMASI VEYA UYGULANMAMASI HAKKINDA VERECEĞi KARARLARA KARŞI BAŞVURU YOLLARI}

Kurul'un idari yaptırım hakkında vereceği kararlara karşı idari bir başvuru yolu, kanun koyucu tarafından 6701 sayılı Kanun kapsamında düzenlenmemiştir. Zorunlu bir idari başvurunun bulunmaması halinde doğrudan yargısal yola başvurulabilecektir.

Kurulun vereceği karar türlerinin ayrımıbakımından başvurulacakyargısal yollar da farklılaşmaktadır.

\section{Kurul'un Idari Yaptırım Kararlarına Karşı Başvuru Yolları}

\section{a. Kurul'un Idari Para Cezası Kararına Karşı Başvuru Yolu}

6701 sayılı Kanun kapsamında Kurul'un uygulayacağı idari yaptırım kararları bakımından 5326 sayılı Kabahatler Kanunu'nun uygulanacağı belirtilmiştir ${ }^{115}$. Dolayısıyla idari para cezasının tebliğinden

111 Düğmeci, s.370.

112 Kalabalık, s.355.

113 Kurul'un 16.06.2020 tarih ve 2020/143 sayıll kararı.

114 Turgut Tan, İdare Hukuku, Güncelleştirilmiş 2. Bası, Turhan Kitabevi, Ankara, Eylül 2013, 414; Yıldırım / Yasin / Karan / Üstün / Özdemir / Okay Tekinsoy, s.379.

11535772 sayı ve 25772 tarihli Mükerrer Resmi Gazetede yayımlanan 5326 sayı ve 30.03.2005 kabul tarihli Kabahatler Kanunu. 
itibaren onbeş gün içinde sulh ceza hâkimliğinde, idari para cezasının iptali için başvuru yapılması gereklidir ${ }^{116}$.

Kurul geçmiş kararlarında, idari yaptırım kararlarına karşı yargısal başvuru yolu olarak Ankara İdare Mahkemesi göstermektedir. Tebliğden itibaren 60 gün içinde iptal davasının açılması gerektiği belirtilmiştir ${ }^{117}$. Ancak ilgili kararlarda yer alan karşı oy yazılarında, sulh ceza hâkimliğine onbeş gün içinde başvurulması gerektiği ifade edilmiştir. Daha sonraki süreçte yayınlanan bir kararda ise sadece yargı yolunun açık olduğu yazılmaktadır ${ }^{118}$. Ancak Kurul'un son verdiği kararlar yönünden artık açı bir şekilde Ankara Sulh Ceza Mahkemelerinde onbeş gün içinde dava açılması gerektiği belirtilmiştir ${ }^{119}$. Kurulun görüşünü bu yönde değiştirerek, başvuru merciini açık bir şekilde belirtmesi, Kurul'un verdiği kararlara karşı başvuru yolunun kullanılabilmesi anlamında adil yargılanma hakkının sağlandığını göstermektedir.

İdari yaptırım kararına karşı başvurulacak merciin belirtilmemiş olması, yanlış görevli yere başvurulması kapsamında başvuru hakkının kaybına neden olabileceği için TïHEK’in son dönemde kararlarında değişime gitmesi gerekmiştir.

\section{b. Kurul'un Uyarı Cezası Kararına Karşı Başvuru Yolu}

Ayrımcılık yasağının ihlali gerekçesiyle hakkında uyarı cezası uygulananların, kararın iptal edilebilmesi için yargıya başvurma hakkına sahip olmaları, adli yargılanma hakkının kullanılması açısından önem arz etmektedir.

İdari işlem niteliği bulunan uyarı cezasının uygulanmasına karşı başvurulacak yargısal yolun, idari yargı yolu olduğu açıktır. 2577 sayılı İdari Yargılama Usulü Kanunu’nun “İdari davalarda genel yetki” başlıklı 32. maddesi kapsamında, idari işlemi tesis eden idarenin bulunduğu yerdeki idare mahkemesi yetkilidir ${ }^{120}$. Bu doğrultuda Ankara merkezli TïHEK’in verdiği uyarı cezasına ilişkin kararının iptali için menfaat sahibi ilgililerin, Ankara İdare Mahkemesi’nde iptal davası açması gerekecektir.

Uyarı cezasına karşı yapılacak hukuksal başvuru bakımından TİHEK, 2577 sayılı İdari Yargılama Usulü Kanunu’nun 32. madde kapsamında değerlendirmede bulunmuştur. Kurul’un verdiği uyarı cezası kararlarında, kararın iptali için yapılacak başvurunun Ankara İdare Mahkemesi’ne altmış gün içinde yapılması gerektiği belirtilmiştir ${ }^{121}$.

1165326 sayılı Kabahatler Kanunu’nun "Başvuru yolu” başlıklı 27. maddesi.

117 Kurul'un 15.10.2018 tarih ve 2018/97 sayll kararı; Kurul'un 05.03.2019 tarih ve 2019/15 sayll kararı; Kurul'un 10.09.2019 tarih ve 2019/54 sayll karar1; Kurul'un 14.01.2020 tarih ve 2020/8 say1l kararı; Kurul'un 11.02.2020 tarih ve 2020/26 saylı karar1.

118 Kurul'un 11.08.2020 tarih ve 2020/176 say1l kararı.

119 Kurul'un 25.08.2020 tarih ve 2020/182 sayılı kararı.

12017580 sayı ve 20.01.1982 tarihli Resmi Gazete’de yayımlanan 2577 sayı ve 06.01.1982 kabul tarihli İdari Yargılama Usulü Kanunu.

121 Kurul'un 25.08.2020 tarih ve 2020/945 sayll kararl; Kurul'un 08.09.2020 tarih ve 2020/193 sayıl kararl; Kurul'un 22.09.2020 tarih ve 2020/198 sayll kararı. 


\section{Kurul'un Idari Yaptırımın Uygulanmaması Kararına Karşı Başvuru Yolu}

Ayrımcılık yasağının ihlali iddiası ile TİHEK’e başvurulması kapsamında somut olayın incelenmesi sonucunda ihlalin varlığının tespit edilmesi gibi kimi durumlarda da ihlalin var olmadığına dair karar verilebilmektedir. Bu yönde verilen kararın da bir idari işlem niteliğinde olduğu açıktır. Bu nedenle Kurul'un kendisine başvuru üzerine verdiği kararın, ihlal iddiasında bulunanlara da tebliğ edilmesi gereklidir.

Ayrımcılık yasağının ihlal edilmediğine dair verilecek karar, Türkiye İnsan Hakları ve Eşitlik Kurumu Kanunun Uygulanmasına İlişkin Usul ve Esaslar Hakkında Yönetmelik’in “Gerekçeli kabul edilmezlik kararı” başlıklı 67. maddesi kapsamında bir kabul edilmezlik kararıdır. Kararın kendisine tebliğ edilmesi üzerine başvurucular, 2577 sayılı Kanun 32. madde uyarınca, Ankara İdare Mahkemesi’nde, kararın kendilerine tebliğ edilmesini izleyen altmış gün içinde iptal davası açma hakkına sahiptirler.

\section{SONUÇ}

Küreselleşmenin yoğun olarak insan haklarının korunması bağlamında etkin olması ve temel hak ve özgürlükleri koruma bilincinin gün geçtikçe artması, devletlerin bu alanda faaliyet gösteren kurum ve kuruluşlarının artmasını sağlamıştır. TİHEK, yıllar içerisinde bağlayıcı karar alma yetkisinin de kendisine tanınmasıyla bu etkinin en önemli örneklerinden biri olarak karşımıza çıkmaktadır.

TİHEK'in idari yaptırım yetkisine sahip olması, kendisini diğer ulusal insan haklarını koruma faaliyetinde bulunan kurumlardan ayırmaktadır. 6701 sayılı Kanun bakımından sadece ayrımcılık yasağının ihlal edilmesi kapsamında bu yetkinin kullanılması söz konusu olmaktadır.

Diğer düzenleyici ve denetleyici kurumlara nazaran hukukumuzda yeni bir kimliğe sahip olan TİHEK'in özellikle verdiği kararlar ile yaptırım gücünün, sınırlarının ve denetiminin kapsamı belirlenmeye çalışılmaktadır. İhlallerin tespitinde, düzenleyici işlemler yerine ağırlıkla Kurul'un takdir yetkisi kullanılmaktadır.

İhlalin tespit edilmesi bakımından yapılan değerlendirmeler kadar, ihlalin tespit edilmesi sonucu uygulanacak idari yaptırımın türünü ve ölçüsünü belirlemek üzere yapılacak değerlendirmeler de önemlidir. Diğer bir deyişle hukuka aykırı davranışın yaptırım ile karşılık bulmasında idari yaptırım ile yasaklı bu davranış arasında ölçülülüğün korunması gerekmektedir. Bu kapsamda idari yaptırımın niceliksel yapısının belirlenmesinde sınırın önceden çizilmesi şarttır. İdari yaptırım sınırının belirlenmesinde, yazılı hukuk metinlerin varlığı önem taşımaktadır. 6701 sayılı Kanunun 25. maddesi idari yaptırım kararı alınırken uygulanacak alt ve üst sınırı belirlemekle hukuki öngörülebilirlik ilkesini sağlamıştır. Bu alt ve üst sınırın somut olaydaki ayrımcılık ihlali fiiline uygulanabilmesi adına Kurul'un ileride yürürlüğe koyacağı çeşitli düzenleyici işlemlerle, belirginliğin daha da çok artacağı açıktır. Bu nedenle Kurul'un şu ana kadar yaptığı ihlal incelemelerinden yararlanarak hazırlayacağı düzenleyici işlemler, hem Kurul'un karar alma sürecini kolaylaştıracak hem de hukuki öngörülebilirlik ilkesini sağlamlaştıracaktır. 
İdari yaptırımların uygulanması bakımından Kurulun alacağı kararlarda uyarı cezası verilmesi yönünde daha bağlayıcı norm hükümlerinin bulunması, hukuki öngörülebilirlik ilkesi adına yerinde olacaktır.

Özellikle Kurul’un son dönemde vermiş olduğu kararlar ile idari yaptırımlara karşı başvuru yolunu, 5326 sayılı Kabahatler Kanunu kapsamında Sulh Ceza Hakimliği olarak belirtmesi, adil yargılanma hakkının sağlanmasını kuvvetlendirmiştir.

\section{KAYNAKÇA}

Mehmet Akad / Bihterin Vural Dinçkol / Nihat Bulut, Genel Kamu Hukuku, Gözden Geçirilmiş 16. Basım, Der Yayınevi, İstanbul, 2020.

Müslüm Akıncı, Bağımsız İdari Otoriteler ve Ombudsman, Beta Yayınları, İstanbul, 1999.

Bahtiyar Akyılmaz / Murat Sezginer / Cemil Kaya, Türk İdare Hukuku,12. Baskı, Savaş Yayınevi, Ankara, Eylül 2020.

Şükrü Altıntaş, Türkiye’de İnsan Haklarının Gelişimi ve Kurumsal Yapılanması: İnsan Hakları ve Eşitlik Kurumu Örneği, Karamanoğlu Mehmetbey Üniversitesi Sosyal Bilimler Enstitüsü yayımlanmamış Yüksek Lisans Tezi, Karaman, 2019.

Ender Ethem Atay, "Bağımsız İdari Otoriteler ve Türkiye Uygulaması”, Gazi Üniversitesi Hukuk Fakültesi Dergisi, Cilt: X, Say1:1-2, 2006, s.259 - 293.

Ender Ethem Atay, "Hukuk Devleti İlkesi Işı̆̆ında İdarenin Denetimi ve Kamu Denetçilĭği”, Ombudsman Akademik Dergisi, Say1: 1, 2014, s.1 - 30.

Tülin Çağdaş, "Ombudsman Kurumu ve Türkiye’de 6328 Sayılı "Kamu Denetçiliği Kurumu Kanunu”nun Düzenlenmesi”, İstanbul Medipol Üniversitesi Hukuk Fakültesi Dergisi, Cilt: 4, Sayı: 2, Güz 2017, s.83 $-107$.

Abdullah Dinçkol, Hukuk Sosyolojisine Giriş, Der Yayınları, 2. Baskı, İstanbul 2021.

Lütfi Duran, İdare Hukuku Ders Notları, İstanbul, 1982.

Fatih Düğmeci, Türkiye İnsan Hakları ve Eşitli Kurumu’nun Yapısı ve İdare Üzerindeki Ayrımcılık Denetimi, 1. Baskı, Adalet Yayınevi, Ankara, 2019.

Abdurrahman Eren, 12-13 Haziran 2015 tarihinde sunulan bildiri, Ulusal İnsan Hakları Kurumları (İyi Uygulama Örnekleri ve Deneyim Paylaşımı) Uluslararası Konferansı, İstanbul, Kasım 2015.

Hayrettin Eren, Türkiye İnsan Hakları ve Eşitlik Kurumu, 1. Baskı, Adalet Yayınevi, Ankara, 2016.

Kemal Gözler, İdare Hukuku Cilt: I, 2. Baskı, Ekin Basın Yayın Dağıtım, Bursa, 2009.

Mesut Gülmez, İnsan Hakları ve Avrupa Birliği Hukukunda Ayrımcılığın Kaldırılması ve Türkiye, AB’ye Sosyal Uyum Dizisi, Ankara, 2009.

Ümran Güneş, “Türkiye’de İnsan Haklarının Korunmasına İlişkin Ulusal İnsan Hakları Kurumları: Kamu Denetçiliği Kurumu ve Türkiye İnsan Hakları ve Eşitlik Kurumu”, Trakya Üniversitesi Sosyal Bilimler Dergisi, Cilt: 20, Sayı: 1, Haziran 2018, s.165 - 186.

Halil Kalabalık, İnsan Hakları Hukuku, 5. Baskı, Seçkin Yayınevi, Ankara, 2017.

Gürsel Kaplan, İdari Yargılama Hukuku, 3. Baskı, Ekin Basın Yayın Dağıtım, Bursa, Ocak 2018.

Ulaş Karan, "Eşitlik İlkesi ve Ayrımcılık Yasağı”, İnsan Hakları Avrupa Sözleşmesi ve Anayasa, 3. Baskı, Beta Yayınevi, İstanbul, s.460 - 493. 
İbrahim Keskin, “Temel İnsan Hakları Bağlamında Ombudsmanlık Kurumunun Hukuku Devletindeki Yeri ve Önemi”, Adalet Dergisi, Say1: 45, 2013, s.117 - 144.

Zehra Odyakmaz / Bayram Keskin / Yusuf Deniz, “6701 Sayılı Türkiye İnsan Hakları ve Eşitlik Kurumu Kanunu Üzerine Bir Değerlendirme - I”, Uyuşmazlık Mahkemesi Dergisi, Sayı: 7, 2016, s.721 - 761.

Zehra Odyakmaz, "Kamu Denetçiliği (Ombudsmanlık) Kurumunun Tanıtılması ve 6328 Sayılı Kanunun Bazı Maddelerinin Değerlendirilmesi”, Türkiye Adalet Akademisi Dergisi, Cilt: 4, Sayı: 14, 2013, s.1 - 85.

Vahap Atilla Oğuşgil, “Avrupa Birliği Yolunda Türkiye İnsan Hakları Kurumu’nun Birleşmiş Milletler Paris Prensipleri Ișığında Değerlendirilmesi”, Bilig (Türk Dünyası Sosyal Bilimler Dergisi), Sayı: 74, Yaz 2015, s.175 - 198.

D. Çiğdem Sever, “Türkiye’de Düzenleyici kurumların Yapısı, İşlevi ve Dönüşümü”, Ankara Üniversitesi Hukuk Fakültesi Dergisi, Cilt: 64, Sayı:1, 2015, s.195 - 236.

Turgut Tan, “Bağımsız İdari Otoriteler veya Düzenleyici Kurullar”, Amme İdaresi Dergisi, Cilt: 35, Sayı: 2, Haziran 2002, s.11 --37.

Turgut Tan, Ekonomik Kamu Hukuku, Turhan Kitabevi, Ankara, Şubat 2010.

Turgut Tan, İdare Hukuku, Güncelleștirilmiş 2. Bası, Turhan Kitabevi, Ankara, Eylül 2013.

Ali D. Ulusoy, Bağımsız İdari Otoriteler, Turhan Kitabevi, Ankara, 2003.

Ali D. Ulusoy, Yeni Türk İdare Hukuku, Gözden Geçirilmiş 3. Baskı, Yetkin Yayınları, Ankara, 2020.

Emrah Uran, Türkiye’deki Bağımsız İdari Otoritelerin İdari Yaptırım Yetkisi, 1. Baskı, Oniki Levha Yayıncılık, İstanbul, Ağustos 2012.

Hasan Nuri Yaşar / S. Sena Cabığlu Güler, "Düzenleyici ve Denetleyici Kurumların Yetkileri Kapsamında Kamu Gücü İlişkisi”, Gazi Üniversitesi Hukuk Fakültesi Dergisi, Cilt: XX, Sayı: 4, 2016, s.63 - 80.

Turan Yıldırım, “Bağımsız İdari Otoritelerin Yargısal Denetimi”, 2000 Yılı İdari Yargı Sempozyumu, Danıştay Yayın1, No: 59, 2000, s.201 - 206.

Turan Yıldırım / Melikşah Yasin / Nur Kaman / H. Eyüp Özdemir / Gül Üstün / Özge Okay Tekinsoy, İdare Hukuku, Güncelleştirilmiş 7. Baskı, Oniki Levha Yayıncıllk, İstanbul, Ekim 2018.

Mehmet Yüce / Atanur Beyce, Kamu Denetçiliği Hukuku, Savaş Yayınevi, Ankara, Kasım 2013. 